\title{
Factors affecting intake, metabolism and health benefits of phenolic acids: do we understand individual variability?
}

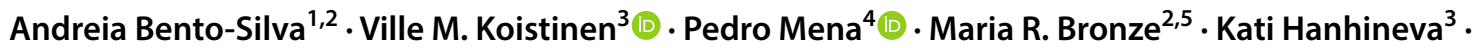

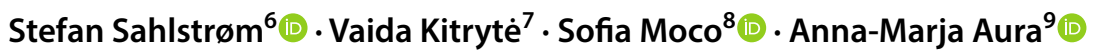

Received: 14 February 2019 / Accepted: 3 May 2019 / Published online: 21 May 2019

(c) The Author(s) 2019

\begin{abstract}
Introduction Phenolic acids are important phenolic compounds widespread in foods, contributing to nutritional and organoleptic properties.

Factors affceting individual variability The bioavailability of these compounds depends on their free or conjugated presence in food matrices, which is also affected by food processing. Phenolic acids undergo metabolism by the host and residing intestinal microbiota, which causes conjugations and structural modifications of the compounds. Human responses, metabolite profiles and health responses of phenolics, show considerable individual variation, which is affected by absorption, metabolism and genetic variations of subjects.

Opinion A better understanding of the gut-host interplay and microbiome biochemistry is becoming highly relevant in understanding the impact of diet and its constituents. It is common to study metabolism and health benefits separately, with some exceptions; however, it should be preferred that health responders and non-responders are studied in combination with explanatory metabolite profiles and gene variants. This approach could turn interindividual variation from a problem in human research to an asset for research on personalized nutrition.
\end{abstract}

Keywords Phenolic acids $\cdot$ Colonic metabolites $\cdot$ Bioavailability $\cdot$ Bioactivity $\cdot$ Interindividual variability

Anna-Marja Aura

anna-marja.aura@vtt.fi

1 Instituto de Tecnologia Química e Biológica, Universidade Nova de Lisboa (ITQB NOVA), Oeiras, Portugal

2 Faculty of Pharmacy, University of Lisbon, Lisbon, Portugal

3 Department of Clinical Nutrition, University of Eastern Finland, Kuopio, Finland

4 Human Nutrition Unit, Department of Food and Drugs, University of Parma, Parma, Italy

5 Instituto de Biologia Experimental Tecnológica (iBET), Oeiras, Portugal

$6 \quad$ Nofima Norwegian Institute of Food Fisheries and Aquaculture, Ås, Norway

7 Kaunas University of Technology, Kaunas, Lithuania

8 Nestlé Institute of Health Sciences, Nestlé Research, Lausanne, Switzerland

9 VTT Technical Research Centre of Finland Ltd, P.O. Box 1000, Tietotie 2, 02044 VTT Espoo, Finland

\author{
Abbreviations \\ ARE Antioxidant-response element \\ BMI Body mass index \\ FMD Flow-mediated dilation \\ GIP Glucose-dependent insulinotropic polypeptide \\ GLP-1 Glucagon-like peptide-1 \\ HBA Hydroxybenzoic acids \\ HCA Hydroxycinnamic acids \\ LAB Lactic acid bacteria \\ PAD Phenolic acid decarboxylase
}

\section{Sources, intake and bioavailability of phenolic acids}

Phenolic acids are a class of secondary metabolites, part of a large group of phenolic compounds, widely distributed in the plant kingdom. They are considered important constituents of food, contributing to taste, colour and nutritional properties. Based on their chemical structure, phenolic acids can be classified into benzoic acid and cinnamic acid derivatives (Fig. 1). Hydroxycinnamic acids (HCAs) are synthetized in 


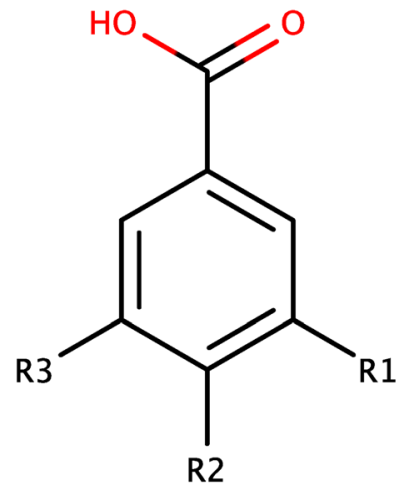

1, R1 = R2 = R3 = H, Benzoic acid

2, $\mathrm{R} 1=\mathrm{R} 2=\mathrm{R} 3=\mathrm{OH}$, Gallic acid

3, $\mathrm{R} 1=\mathrm{R} 2=\mathrm{OH}, \mathrm{R} 2=\mathrm{H}$, Protocatechuic acid

4, $\mathrm{R} 1=\mathrm{R} 3=\mathrm{H}, \mathrm{R} 2=\mathrm{OH}, p-\mathrm{Hydroxybenzoic}$ acid

5, R1 $=\mathrm{OCH}_{3}, \mathrm{R} 2=\mathrm{OH}, \mathrm{R} 3=\mathrm{H}$, Vanillic acid

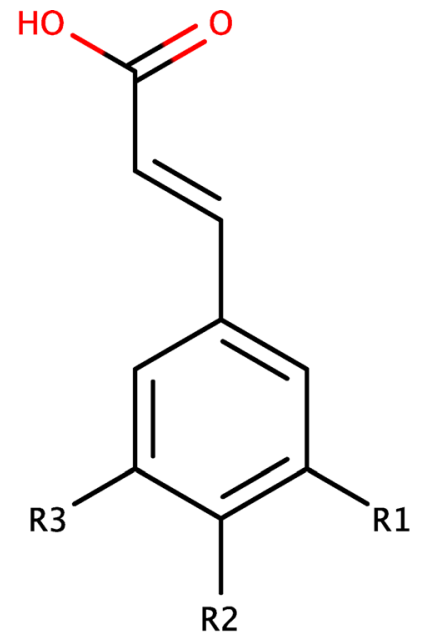

6, $R 1=R 2=R 3=H$, Cinnamic acid

7, $\mathrm{R} 1=\mathrm{R} 2=\mathrm{OH}, \mathrm{R} 3=\mathrm{H}$, Caffeic acid

8, $\mathrm{R} 1=\mathrm{R} 3=\mathrm{H}, \mathrm{R} 2=\mathrm{OH}, p$-Coumaric acid

9, $\mathrm{R} 1=\mathrm{OCH}_{3}, \mathrm{R} 2=\mathrm{OH}, \mathrm{R} 3=\mathrm{H}$, Ferulic acid

10, R1 = R3 = $\mathrm{OCH}_{3}, \mathrm{R} 2=\mathrm{OH}$, Sinapic acid

Fig. 1 Structures of benzoic acid (1), common hydroxybenzoic acids (2-5) and common hydroxycinnamic acids (6-10)

plants from phenylalanine via cinnamic acid or directly from tyrosine by tyrosine ammonia-lyase, producing the simplest hydroxycinnamic acid, $p$-coumaric acid, which can be further synthetized into caffeic, ferulic and sinapic acids [1,2].

\section{Sources and intake of hydroxybenzoic acids (HBAs)}

The main hydroxybenzoic acids (HBAs) are gallic acid (3,4,5-trihydroxybenzoic acid), protocatechuic acid (3,4-dihydroxybenzoic acid), and $p$-hydroxybenzoic acid (4-hydroxybenzoic acid) [3]. Particularly high contents of $p$-hydroxybenzoic acid- $O$-glucoside have been found in spices and herbs belonging to the Apiaceae family: anise $730-1080 \mathrm{mg} / \mathrm{kg}$ fresh weight (FW), caraway up to $42 \mathrm{mg} / \mathrm{kg} \mathrm{FW}$, fennel up to $106 \mathrm{mg} / \mathrm{kg} \mathrm{FW}$, and coriander up to $30 \mathrm{mg} / \mathrm{kg} \mathrm{FW} \mathrm{[4].} \mathrm{In} \mathrm{addition,} \mathrm{star} \mathrm{anise} \mathrm{(in} \mathrm{the}$ Schisandraceae family) contains $p$-hydroxybenzoic acid$O$-glucoside $730-840 \mathrm{mg} / \mathrm{kg} \mathrm{FW}$. The concentration of hydroxybenzoic acids in fruits and vegetables is generally low and they are mostly present in conjugated forms [3, 5]. For example, gooseberries, blackberries, and raspberries contain $p$-hydroxybenzoic acid- $O$-glucoside $9-14 \mathrm{mg} / \mathrm{kg}$ $\mathrm{FW}, 4-18 \mathrm{mg} / \mathrm{kg} \mathrm{FW}$, and $32-56 \mathrm{mg} / \mathrm{kg} \mathrm{FW}$, respectively, whereas protocatechuic acid-4- $O$-glucoside contents varies from trace amount to $6 \mathrm{mg} / \mathrm{kg} \mathrm{FW}$ in the same berries, and gallic acid-4- $O$-glucoside up to $3 \mathrm{mg} / \mathrm{kg} \mathrm{FW}$. Blueberries have a different HBA profile, as they contain mainly p-coumaroylquinic acid (1860-2080 mg/kg FW) and only
$4-5 \mathrm{mg} / \mathrm{kg}, 3-6 \mathrm{mg} / \mathrm{kg}$, and $2-9 \mathrm{mg} / \mathrm{kg} \mathrm{FW}$ of $p$-hydroxybenzoic acid- $O$-glucoside, protocatechuic acid-4- $O$-glucoside, and gallic acid-4- $O$-glucoside, respectively [4]. Marionberries and boysenberries have been reported to contain gallic acid $30 \mathrm{mg} / \mathrm{kg}$ and $90 \mathrm{mg} / \mathrm{kg} \mathrm{FW}$, respectively [6]. In addition, chestnuts contain high amounts of gallic acid (3460-9070 mg/kg FW) [7]. Onion peel contains HBAs, mainly protocatechuic acid-4-O-glucoside in a concentration of $91 \mathrm{mg} / \mathrm{kg} \mathrm{FW}$ [4]. Hydroxybenzoic acids can also be complexed to large structures: gallic acid can form oligomers known as gallotannins, while ellagic acid, the dilactone of hexahydroxydiphenic acid, is a constituent of hydrolysable ellagitannins, abundant in, e.g., Rubus berries (2630-3300 mg/kg FW), pomegranate juice (1500-1900 mg/l), and walnuts (16,040 mg/kg FW) [8].

\section{Sources and intake of hydroxycinnamic acids (HCAs)}

HCAs are widely distributed in plants [2], occurring in nature generally as esters (formed by conjugation with quinic, shikimic, and tartaric acids, flavonoids, or carbohydrates), or as amides (formed by conjugation with amino acids or amines) $[2,9,10]$. High concentrations of HCAs can be found in many food products, such as coffee, tea, wine, cocoa, fruits, vegetables, and cereals. Their exact level varies among plant food varieties [11]. Free and simple HCA esters are abundant in fruits and vegetables, while bound HCA derivatives are more common in grains. 
HCA-derived amides are mostly found in coffee and cocoa [2]. Caffeic acid and coumaric acid are abundant in fruits, such as apples, pears and berries, representing between 75 and $100 \%$ of the total HCA content of most fruits [9]. Some of the richest sources of caffeic acid include wild blueberry (1470 mg/kg FW), coffee ( $870 \mathrm{mg} / \mathrm{kg} \mathrm{FW})$, carrot (260 mg/ $\mathrm{kg} \mathrm{FW})$, plum (234 mg/kg FW), and aubergine $(210 \mathrm{mg} / \mathrm{kg}$ FW) [2, 12]. Caftaric acid (2-caffeoyltartaric acid), a caffeic acid derivative, is an important phenolic compound in wine (6-73 mg/l in white wine, $46-141 \mathrm{mg} / \mathrm{l}$ in red wine) $[2,13$, 14]. Among the most abundant free HCA derivatives are chlorogenic acids, formed by the conjugation of quinic acid with certain HCAs, most commonly caffeic, $p$-coumaric, or ferulic acid $[10,15,16]$. The main subgroups of chlorogenic acids are caffeoylquinic, dicaffeoylquinic, feruloylquinic and $p$-coumaroylquinic acids [10]. Chlorogenic acids are found in many types of fruits and in high concentrations in coffee (depending on climatic and processing conditions, degree of roasting, grinding and barista procedures) [2, 9, 17, 18]. Green coffee beans contain the largest amounts of chlorogenic acids, and some of these are transformed into their corresponding chlorogenic acid lactones during the roasting process; the chlorogenic acid content of roasted coffee beans varies according to the degree of roasting in the range of $2350-80,000 \mathrm{mg} / \mathrm{kg}$ DW [10] and in espresso coffee $890-8130 \mathrm{mg} / 1$ [18]. Chlorogenic acids are also found in vegetables, yerba mate, and tea [2,19]. Ferulic acid is by far the most abundant and common HCA in cereal grains, which are the main dietary source of the compound (intake ranging from 91.5 to $320 \mathrm{mg}$ from wheat bran, rye bran, or whole-grain rye bread in the reported interventions (Table 1; [20-22]), and in whole maize grain [23]. Flavonoid conjugates of ferulic acid and other HCAs have been found in Brassica vegetables (calculated range $200-3600 \mathrm{mg} / \mathrm{kg} \mathrm{DW}$ ) [24-26]. Ferulic acid in its free form exists in tomatoes and beer [9]. Several ferulic acid derivatives, esterified to cell wall polymers in cereal bran, as well as ferulic acid dimers, trimers and tetramers, have been described [27]. The most important sources of sinapic acid are Brassica vegetables, and several conjugated forms of sinapic acid with flavonoids have been described in these vegetables [24-26]. Whole grain cereals are also important sources of sinapic acid [2], which is shown as higher intake of sinapic acid from wholegrain cereals (17-37.3 mg; Table 1) than from white wheat bread $(2.2 \mathrm{mg}$; Table 1) [21, 22]. Coumaric acid (especially $p$-coumaric acid) is also an abundant HCA in most fruits and cereals. It is abundant in strawberries $(1110 \mathrm{mg} / \mathrm{kg} \mathrm{DW})$, other berries (14-950 mg/kg DW), peanuts $(1030 \mathrm{mg} / \mathrm{kg}$ $\mathrm{FW})$, rye bran $(140 \mathrm{mg} / \mathrm{kg} \mathrm{FW})$, and red wine $(50 \mathrm{mg} / \mathrm{kg}$ FW) [2].

\section{Bioavailability of phenolic acids}

Phenolic acids in cereals are present both in free form and bound by ester bonds to arabinoxylan chains or by ether bonds to lignin. Most of the dietary fibre-bound phenolic acids in cereals are esterified to the cell walls. Ferulic acid can dimerize into dehydrodimers that cross-link arabinoxylan chains and/or lignins and thereby affect the physical properties of cell walls and consequently the solubility and degradability of arabinoxylans in the colon [28]. The main ferulic acid dehydrodimers identified in barley and oats are 8-O-4-diferulic acid, 5,5'-diferulic acid and 8,5-diferulic acid (benzofuran form). The intake of dimers was observed by Kern et al. [29], but only a minor part of ferulic and sinapic acids were detected from the urinary excretion (Table 1). The content of dehydrodimers and ferulic acid seems to correlate with the content of insoluble dietary fibre and was found to be $3599 \pm 69$ and $3658 \pm 170 \mathrm{mg} / \mathrm{kg}$ in oats and barley, respectively, with much lower contents detected in soluble dietary fibre fractions of the two cereals (38 \pm 5 and $69 \pm 10 \mathrm{mg} / \mathrm{kg}$ ), respectively [28]. The dehydrodimers are abundant also in the insoluble dietary fibre of maize (12 596 $\left.\pm 184 \mathrm{mg} / \mathrm{kg}^{-1}\right)$, wheat $(2375 \pm 36 \mathrm{mg}$ / $\mathrm{kg})$, spelt $(2601 \pm 59 \mathrm{mg} / \mathrm{kg})$, rice $(4042 \pm 59 \mathrm{mg} / \mathrm{kg})$, wild rice $(2840 \pm 130 \mathrm{mg} / \mathrm{kg})$, rye $(3647 \pm 132 \mathrm{mg} / \mathrm{kg})$ and millet $(5693 \pm 231 \mathrm{mg} / \mathrm{kg})$, while the content in the soluble dietary fibre is only $59 \pm 3 \mathrm{mg} / \mathrm{kg}$ in maize, $184 \pm 14 \mathrm{mg} / \mathrm{kg}$ in wheat, $233 \pm 43 \mathrm{mg} / \mathrm{kg}$ in spelt, $83 \pm 3 \mathrm{mg} / \mathrm{kg}$ in rye, and $46 \pm 9 \mathrm{mg} / \mathrm{kg}$ in millet, lacking completely in rice and wild rice [28]. Bunzel et al. [28] showed also different profiles in the diferulate species in these crops, indicating varying percentages of $8-5^{\prime}$ isomers in total dehydrodiferulates $37 \%$ (in maize soluble fraction) to 54\% (in rye insoluble fraction), 8-8'-dehydrodiferulates from $16 \%$ in barley insoluble dietary fibre to $46 \%$ in spelt soluble fraction, 5-5'-dehydrodiferulates varying from $7 \%$ in spelt soluble dietary fibre to $25 \%$ in maize insoluble dietary fibre fraction [28]. Although ferulic acid dehydrodimers are common, dehydrodisinapic acids and sinapate-ferulate crossed dehydrodimers are less common but have also been identified in cereal dietary fibre [30].

The biological activities of phenolic acids depend on their bioavailability in vivo. Most phenolic acids in cereals (>99\%) are present in their bound form, and thus they are poorly bioavailable [31]. In berries, the content of bound phenolic acids varies between $>90 \%$ in raspberry and cowberry, $70 \%$ in strawberry, $60-70 \%$ in bilberry, lingonberry, and cloudberry, and 10-30\% in rowanberry and blueberry. Among fruits, the highest contents of phenolic acids are found in dark plum, cherry, citrus fruits, red grape, and some apple varieties. However, the contents in these fruits $(<300 \mathrm{mg} / \mathrm{kg} \mathrm{FW})$ were clearly lower than in the berries with the highest phenolic acid content (590-1030 mg/kg $\mathrm{FW})$. The contents of phenolic acids in beverages varies 
Table 1 Mean concentrations and standard deviations of phenolic acid metabolites found in plasma and urine, after the consumption of foods rich in phenolic acids

\begin{tabular}{|c|c|c|c|c|c|c|c|}
\hline Food source & $\begin{array}{l}\text { Compounds } \\
(\mathrm{mg})\end{array}$ & $\begin{array}{l}\text { Total consumed } \\
(\mathrm{mg})\end{array}$ & Metabolites & $\begin{array}{l}\text { Max conc. in } \\
\text { plasma (nM) }\end{array}$ & $\begin{array}{l}\text { Total in } 24-\mathrm{h} \\
\text { urine }(\mathrm{mg})\end{array}$ & $\begin{array}{l}\text { Number of } \\
\text { subject and } \\
\text { gender }\end{array}$ & References \\
\hline $\begin{array}{l}\text { White wheat } \\
\text { bread fortified } \\
\text { with bio- } \\
\text { processed rye } \\
\text { bran }\end{array}$ & $\begin{array}{l}\text { Ferulic acid } \\
\text { Sinapic acid } \\
p \text {-Coumaric acid }\end{array}$ & $\begin{array}{l}160.6 \\
37.3 \\
5.6\end{array}$ & $\begin{array}{l}\text { Ferulic acid } \\
\text { Sinapic acid } \\
p \text {-Coumaric acid }\end{array}$ & - & $\begin{array}{l}1.66 \pm 0.51 \\
0.23 \pm 0.09 \\
0.02 \pm 0.01\end{array}$ & $\begin{array}{l}6 \text { males } \\
9 \text { females }\end{array}$ & {$[21]$} \\
\hline $\begin{array}{l}\text { White wheat } \\
\text { bread fortified } \\
\text { with native rye } \\
\text { bran }\end{array}$ & $\begin{array}{l}\text { Ferulic acid } \\
\text { Sinapic acid } \\
p \text {-Coumaric acid }\end{array}$ & $\begin{array}{l}122.7 \\
30.2 \\
5.2\end{array}$ & $\begin{array}{l}\text { Ferulic acid } \\
\text { Sinapic acid } \\
p \text {-Coumaric acid }\end{array}$ & - & $\begin{array}{l}0.45 \pm 0.15 \\
0.12 \pm 0.06 \\
0.02 \pm 0.01\end{array}$ & $\begin{array}{l}6 \text { males } \\
9 \text { females }\end{array}$ & [21] \\
\hline $\begin{array}{l}\text { White wheat } \\
\text { bread }\end{array}$ & $\begin{array}{l}\text { Ferulic acid } \\
\text { Sinapic acid } \\
p \text {-Coumaric acid }\end{array}$ & $\begin{array}{l}8.4 \\
2.2 \\
0.3\end{array}$ & $\begin{array}{l}\text { Ferulic acid } \\
\text { Sinapic acid } \\
p \text {-Coumaric acid }\end{array}$ & - & $\begin{array}{l}0.27 \pm 0.10 \\
0.06 \pm 0.03 \\
0.01 \pm 0.01\end{array}$ & $\begin{array}{l}6 \text { males } \\
9 \text { females }\end{array}$ & [21] \\
\hline Rye bread & $\begin{array}{l}\text { Ferulic acid } \\
\text { Sinapic acid } \\
p \text {-Coumaric acid }\end{array}$ & $\begin{array}{l}91.5 \\
21.1 \\
3.6\end{array}$ & $\begin{array}{l}\text { Ferulic acid } \\
\text { Sinapic acid } \\
p \text {-Coumaric acid }\end{array}$ & - & $\begin{array}{l}0.33 \pm 0.14 \\
0.07 \pm 0.06 \\
0.01 \pm 0.01\end{array}$ & $\begin{array}{l}6 \text { males } \\
9 \text { females }\end{array}$ & [21] \\
\hline $\begin{array}{l}\text { Whole wheat } \\
\text { bread contain- } \\
\text { ing native bran }\end{array}$ & $\begin{array}{l}\text { Ferulic acid } \\
\text { Sinapic acid } \\
p \text {-Coumaric acid } \\
\text { Vanillic acid }\end{array}$ & $\begin{array}{l}320 \\
17 \\
5.4 \\
4.9\end{array}$ & $\begin{array}{l}\text { Ferulic acid } \\
\text { Sinapic acid } \\
p \text {-Coumaric acid } \\
\text { Vanillic acid }\end{array}$ & $\begin{array}{l}880(150)^{*} \\
\mathrm{n} / \mathrm{d} \\
\mathrm{n} / \mathrm{d} \\
110(30)^{*}\end{array}$ & $\begin{array}{l}9.9(1.9)^{*} \\
1.1(0.8)^{*} \\
0.1(0.07)^{*} \\
5.0(1.3)^{*}\end{array}$ & 8 males & {$[22]$} \\
\hline $\begin{array}{l}\text { Whole wheat } \\
\text { bread contain- } \\
\text { ing bio- } \\
\text { processed bran }\end{array}$ & $\begin{array}{l}\text { Ferulic acid } \\
\text { Sinapic acid } \\
p \text {-Coumaric acid } \\
\text { Vanillic acid }\end{array}$ & $\begin{array}{l}220 \\
17 \\
5.4 \\
4.9\end{array}$ & $\begin{array}{l}\text { Ferulic acid } \\
\text { Sinapic acid } \\
p \text {-Coumaric acid } \\
\text { Vanillic acid }\end{array}$ & $\begin{array}{l}2700(630)^{*} \\
\mathrm{n} / \mathrm{d} \\
\mathrm{n} / \mathrm{d} \\
250(180)^{*}\end{array}$ & $\begin{array}{l}21.4(8.9)^{*} \\
2.7(0.7)^{*} \\
0.09(0.05)^{*} \\
8.2(5.7)^{*}\end{array}$ & 8 males & {$[22]$} \\
\hline Rye bran bread & Ferulic acid & 10.2 & Ferulic acid & - & $4.82 \pm 3.46$ & 18 females & {$[55]$} \\
\hline $\begin{array}{l}\text { Wholegrain } \\
\text { wheat bread }\end{array}$ & Ferulic acid & 87 & $\begin{array}{l}\text { Ferulic acid-4'-O- } \\
\text { sulfate } \\
\text { Dihydroferulic } \\
\text { acid-4'- } O \text {-sulfate } \\
\text { Dihydroferulic } \\
\text { acid- } O \text {-glucuro- } \\
\text { nide }\end{array}$ & $\begin{array}{l}84.3 \pm 16.6 \\
9.2 \pm 1.4 \\
\mathrm{n} / \mathrm{d}\end{array}$ & $\begin{array}{l}P \\
P \\
P\end{array}$ & $\begin{array}{l}8 \text { males } \\
7 \text { females }\end{array}$ & [87] \\
\hline $\begin{array}{l}\text { Commercial } \\
\text { wheat bread } \\
\text { enriched in } \\
\text { aleurone frac- } \\
\text { tion }\end{array}$ & Ferulic acid & 43 & $\begin{array}{l}\text { Ferulic acid-4'-O- } \\
\text { sulfate } \\
\text { Dihydroferulic } \\
\text { acid-4'- } O \text {-sulfate } \\
\text { Dihydroferulic } \\
\text { acid- } O \text {-glucuro- } \\
\text { nide }\end{array}$ & $\begin{array}{l}55.5 \pm 9.4 \\
9.5 \pm 3.5 \\
\mathrm{n} / \mathrm{d}\end{array}$ & $\begin{array}{l}\mathrm{P} \\
\mathrm{P} \\
\mathrm{P}\end{array}$ & $\begin{array}{l}8 \text { males } \\
7 \text { females }\end{array}$ & [87] \\
\hline $\begin{array}{l}\text { Commercial } \\
\text { wheat bread } \\
\text { enriched in } \\
\text { aleurone frac- } \\
\text { tion }\end{array}$ & Ferulic acid & 87 & $\begin{array}{l}\text { Ferulic acid-4'-O- } \\
\text { sulfate } \\
\text { Dihydroferulic } \\
\text { acid-4'- } O \text {-sulfate } \\
\text { Dihydroferulic } \\
\text { acid- } O \text {-glucuro- } \\
\text { nide }\end{array}$ & $\begin{array}{l}76.6 \pm 9.1 \\
11.9 \pm 1.9 \\
\text { n/d }\end{array}$ & $\begin{array}{l}P \\
P \\
P\end{array}$ & $\begin{array}{l}8 \text { males } \\
7 \text { females }\end{array}$ & [87] \\
\hline
\end{tabular}


Table 1 (continued)

\begin{tabular}{|c|c|c|c|c|c|c|c|}
\hline Food source & $\begin{array}{l}\text { Compounds } \\
(\mathrm{mg})\end{array}$ & $\begin{array}{l}\text { Total consumed } \\
(\mathrm{mg})\end{array}$ & Metabolites & $\begin{array}{l}\text { Max conc. in } \\
\text { plasma (nM) }\end{array}$ & $\begin{array}{l}\text { Total in 24-h } \\
\text { urine (mg) }\end{array}$ & $\begin{array}{l}\text { Number of } \\
\text { subject and } \\
\text { gender }\end{array}$ & References \\
\hline $\begin{array}{l}\text { Commercial } \\
\text { breakfast } \\
\text { cereal ( } 85 \% \\
\text { wheat bran) }\end{array}$ & $\begin{array}{l}\text { Vanillin } \\
t \text { - } p \text {-Coumaric } \\
\quad \text { acid } \\
\text { trans-Sinapic } \\
\quad \text { acid } \\
t \text {-Ferulic acid } \\
\text { cis-Ferulic acid } \\
\text { 8-5-diFA (open } \\
\text { form) } \\
\text { 5-5-diFA } \\
\text { 8-O-4-diFA } \\
\text { 8-5-Benzofuran- } \\
\text { diFA }\end{array}$ & $\begin{array}{l}2.72 \pm 0.40 \\
5.44 \pm 0.45 \\
19.60 \pm 1.73 \\
259.10 \pm 15.63 \\
9.22 \pm 4.96 \\
4.94 \pm 0.18 \\
6.43 \pm 0.24 \\
14.46 \pm 1.92 \\
2.85 \pm 0.75\end{array}$ & $\begin{array}{l}\text { Ferulic acid } \\
\text { Sinapic acid }\end{array}$ & $\begin{array}{l}150 \text { to } 210 \\
\sim 10 \text { to } 40\end{array}$ & $\begin{array}{l}8.10 \pm 3.34 \\
0.54 \pm 0.13\end{array}$ & $\begin{array}{l}3 \text { males } \\
3 \text { females }\end{array}$ & [29] \\
\hline Cranberry juice & $\begin{array}{l}\text { Cinnamic acid } \\
p \text {-Coumaric acid } \\
\text { Caffeic acid } \\
\text { Ferulic acid } \\
\text { Chlorogenic acid } \\
\text { Benzoic acid } \\
\text { 2-Hydroxyben- } \\
\text { zoic acids } \\
\text { 3,4-Dihydroxy- } \\
\text { benzoic acid } \\
\text { Gallic acid } \\
\text { Vanillic acid }\end{array}$ & $\begin{array}{l}1.0 \\
6.9 \\
1.2 \\
0.0 \\
5.2 \\
7.8 \\
0.1 \\
1.1 \\
0.1 \\
1.0\end{array}$ & $\begin{array}{l}\text { Selected metabo- } \\
\text { lites } \\
\text { Cinnamic acid } \\
\text { p-Coumaric acid } \\
\text { Caffeic acid } \\
\text { Ferulic acid } \\
\text { Chlorogenic acid } \\
\text { Ferulic acid-4'-O- } \\
\text { sulfate } \\
\text { Ferulic acid-4'-O- } \\
\text { glucuronide } \\
\text { Dihydroferulic acid } \\
\text { Benzoic acid } \\
\text { 2,3-Dihydroxyben- } \\
\text { zoic acids } \\
\text { Protocatechuic acid } \\
\text { Syringic acid } \\
\text { Vanillic acid } \\
\text { Vanillic acid-4-O- } \\
\text { sulfate } \\
\text { Isovanillic acid } \\
\text { 4-Methylgallic } \\
\text { acid-3-O-sulfate } \\
\text { Hippuric acid } \\
\alpha-H y d r o x y h i p p u r i c \\
\text { acid } \\
\text { 2-(4-Hydroxyphe- } \\
\text { noxy)propionic } \\
\text { acid } \\
\text { Homovanillic acid } \\
\text { 3,4-Dihydroxyphe- } \\
\text { nyl acetic acid } \\
\text { 3-Hydroxyphenyl } \\
\text { acetic acid } \\
\text { 4-Hydroxyphenyl } \\
\text { acetic acid }\end{array}$ & $\begin{array}{l}123 \pm 34 \\
6 \pm 1 \\
1 \pm 1 \\
57 \pm 12 \\
5 \pm 2 \\
2268 \pm 794 \\
165 \pm 29 \\
304 \pm 122 \\
2169 \pm 608 \\
12,024 \pm 4055 \\
109 \pm 45 \\
8 \pm 6 \\
410 \pm 115 \\
1054 \pm 274 \\
220 \pm 44 \\
275 \pm 82 \\
42,926 \pm 12282 \\
2943 \pm 587 \\
\text { n.d. } \\
511 \pm 165 \\
476 \pm 138 \\
615 \pm 360 \\
1849 \pm 724\end{array}$ & $\begin{array}{l}n m o l \\
\mathrm{n} / \mathrm{d} \\
36 \pm 9 \\
75 \pm 22 \\
\mathrm{n} / \mathrm{d} \\
52 \pm 25 \\
1055 \pm 259 \\
109 \pm 20 \\
524 \pm 368 \\
4141 \pm 427 \\
8432 \pm 2176 \\
944 \pm 162 \\
249 \pm 31 \\
423 \pm 136 \\
288 \pm 87 \\
1238 \pm 229 \\
297 \pm 74 \\
69,717 \pm 13,686 \\
74,538 \pm 20,636 \\
453 \pm 152 \\
6640 \pm 1472 \\
1597 \pm 297 \\
4384 \pm 922 \\
10,152 \pm 3161\end{array}$ & 10 males & {$[63]$} \\
\hline Coffee & $\begin{array}{l}\text { Caffeoylquinic } \\
\text { acid } \\
\text { Feruloylquinic } \\
\text { acid } \\
\text { Dicaffeoylquinic } \\
\text { acid }\end{array}$ & $\begin{array}{l}256 \\
37 \\
42\end{array}$ & $\begin{array}{l}\text { Dihydroferulic acid } \\
\text { Dihydrocaffeic acid } \\
\text { Caffeic acid } \\
\text { Ferulic acid } \\
\text { Isoferulic acid }\end{array}$ & $\begin{array}{l}\mathrm{P} \text { (major) } \\
\mathrm{P} \text { (major) } \\
\mathrm{P} \text { (minor) } \\
\mathrm{P} \text { (minor) } \\
\mathrm{P} \text { (minor) }\end{array}$ & - & $\begin{array}{l}4 \text { males } \\
5 \text { females }\end{array}$ & {$[62]$} \\
\hline
\end{tabular}


Table 1 (continued)

\begin{tabular}{|c|c|c|c|c|c|c|c|}
\hline Food source & $\begin{array}{l}\text { Compounds } \\
(\mathrm{mg})\end{array}$ & $\begin{array}{l}\text { Total consumed } \\
(\mathrm{mg})\end{array}$ & Metabolites & $\begin{array}{l}\text { Max conc. in } \\
\text { plasma (nM) }\end{array}$ & $\begin{array}{l}\text { Total in 24-h } \\
\text { urine (mg) }\end{array}$ & $\begin{array}{l}\text { Number of } \\
\text { subject and } \\
\text { gender }\end{array}$ & References \\
\hline Instant coffee & $\begin{array}{l}\text { Caffeoylquinic } \\
\text { acids } \\
\text { Feruloylquinic } \\
\text { acids } \\
\text { Caffeoylquinic } \\
\text { acid lactones } \\
\text { Dicaffeoylquinic } \\
\text { acids } \\
p \text {-Cou- } \\
\text { maroylquinic } \\
\text { acids }\end{array}$ & $\begin{array}{l}95.31 \pm 1.74 \\
24.68 \pm 1.95 \\
19.17 \pm 1.65 \\
6.51 \pm 0.62 \\
2.30 \pm 0.03\end{array}$ & $\begin{array}{l}\text { 3- } O \text {-Caffeoylquinic } \\
\text { acid lactone-O- } \\
\text { sulfate } \\
\text { 3- } O \text {-Feruloylquinic } \\
\text { acid } \\
\text { Caffeic acid-3- } O \text { - } \\
\text { sulfate } \\
\text { Ferulic acid-4- } O \text { - } \\
\text { sulfate } \\
\text { Dihydroferulic acid } \\
\text { Dihydroferulic } \\
\text { acid-4- } O \text {-sulfate } \\
\text { Dihydrocaffeic } \\
\text { acid-3- } O \text {-sul- } \\
\text { fate } \ldots \\
\text { And others }\end{array}$ & $\begin{array}{l}27 \pm 3 \\
16 \pm 2 \\
92 \pm 11 \\
76 \pm 9 \\
385 \pm 86 \\
145 \pm 53 \\
325 \pm 99\end{array}$ & $\begin{array}{l}1.1 \pm 0.1 \\
1.2 \pm 0.1 \\
6.4 \pm 0.8 \\
11.1 \pm 1.6 \\
9.7 \pm 2.0 \\
12.4 \pm 3.4 \\
37.1 \pm 8.2\end{array}$ & $\begin{array}{l}8 \text { males } \\
3 \text { females }\end{array}$ & {$[61]$} \\
\hline $\begin{array}{l}\text { Yerba mate infu- } \\
\text { sion }\end{array}$ & $\begin{array}{l}\text { Caffeoylglucose } \\
\text { isomers } \\
\text { Caffeoylquinic } \\
\text { acids } \\
\text { Coumaroylquinic } \\
\text { acids } \\
\text { Feruloylquinic } \\
\text { acids } \\
\text { Caffeoylquinic } \\
\text { lactones } \\
\text { Dicaffeoylquinic } \\
\text { acids } \\
\text { Caffeoylferu- } \\
\text { loylquinic } \\
\text { acids } \\
\text { Flavonols }\end{array}$ & $\begin{array}{l}3.5 \pm 0.2 \\
44.5 \pm 0.8 \\
0.5 \pm 0.1 \\
3.2 \pm 0.1 \\
2.7 \pm 0.2 \\
22.4 \pm 0.5 \\
0.5 \pm 0.1 \\
3.3 \pm 0.3\end{array}$ & $\begin{array}{l}\text { Coumaroylquinic } \\
\text { acid } \\
\text { Caffeic acid 3-sul- } \\
\text { fate } \\
\text { Ferulic acid 4-glu- } \\
\text { curonide } \\
\text { Ferulic acid 4-sul- } \\
\text { fate } \\
\text { Others } \\
\text { Microbial metabo- } \\
\text { lites }\end{array}$ & $\begin{array}{l}\text { Traces } \\
37 \pm 36 \\
11 \pm 4 \\
19 \pm 9 \\
\text { n/d }\end{array}$ & $\begin{array}{l}0.179 \pm 0.033 \\
1.261 \pm 0.330 \\
1.098 \pm 0.278 \\
2.234 \pm 0.701\end{array}$ & $\begin{array}{l}7 \text { males } \\
5 \text { females }\end{array}$ & [19] \\
\hline
\end{tabular}


Table 1 (continued)

\begin{tabular}{|c|c|c|c|c|c|c|c|}
\hline Food source & $\begin{array}{l}\text { Compounds } \\
(\mathrm{mg})\end{array}$ & $\begin{array}{l}\text { Total consumed } \\
(\mathrm{mg})\end{array}$ & Metabolites & $\begin{array}{l}\text { Max conc. in } \\
\text { plasma (nM) }\end{array}$ & $\begin{array}{l}\text { Total in 24-h } \\
\text { urine (mg) }\end{array}$ & $\begin{array}{l}\text { Number of } \\
\text { subject and } \\
\text { gender }\end{array}$ & References \\
\hline $\begin{array}{l}\text { Polyphenol rich } \\
\text { diet } \\
\text { Response after } \\
8 \text { week inter- } \\
\text { vention } \\
N=34\end{array}$ & $\begin{array}{l}\text { Polyphenols } \\
\text { Flavones } \\
\text { Flavonols } \\
\text { Flavanols } \\
\text { Flavanones } \\
\text { Anthocyanidins } \\
\text { Isoflavones } \\
\text { Phenolic acids }\end{array}$ & $\begin{array}{l}\mathrm{mg} \\
2868 \\
7.6 \\
223 \\
1194 \\
102 \\
111 \\
0.02 \\
1245\end{array}$ & 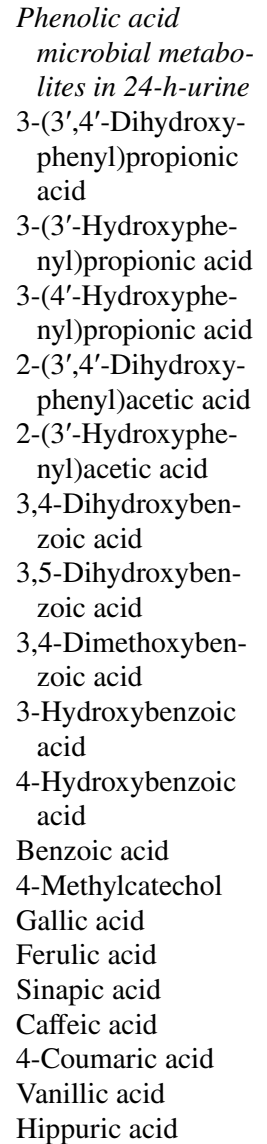 & - & $\begin{array}{l}\text { nmol/mg creati- } \\
\quad \text { nine } \\
0.14 \pm 0.16 \\
0.12 \pm 0.12 \\
0.002 \pm 0.000 \\
0.10 \pm 0.07 \\
0.33 \pm 0.25 \\
0.03 \pm 0.01 \\
0.02 \pm 0.01 \\
0.01 \pm 0.01 \\
0.01 \pm 0.01 \\
0.06 \pm 0.04 \\
0.06 \pm 0.13 \\
0.07 \pm 0.07 \\
0.004 \pm 0.000 \\
0.13 \pm 0.08 \\
0.10 \pm 0.09 \\
0.06 \pm 0.04 \\
0.003 \pm 0.000 \\
0.11 \pm 0.07 \\
23 \pm 20\end{array}$ & $\begin{array}{l}16 \text { males } \\
19 \text { females }\end{array}$ & [85] \\
\hline
\end{tabular}

Conc concentration, $n / d$ not detected, $P$ present, asterisk values are medians, IQR interquartile range (middle 50\%), double asterisks largest standard deviation from the individual components in the sum

widely, ranging from $0 \mathrm{mg} / \mathrm{kg}$ in pear cider, $160 \mathrm{mg} / \mathrm{kg} \mathrm{FW}$ in apple juice, $300-360 \mathrm{mg} / \mathrm{kg} \mathrm{FW}$ in green and black tea to $970 \mathrm{mg} / \mathrm{kg} \mathrm{FW}$ in coffee and $1520 \mathrm{mg} / \mathrm{l}$ in yerba mate [19, 32]. Most of the phenolic acids in beverages are liberated after hydrolysis, indicating that nearly all phenolic acids are conjugated or bound in the original ingredients.

\section{Impact of food matrix and processing on the bioavailability of phenolic acids}

The bioavailability and thus the phenolic acid concentrations in the body fluids measured in intervention trials are affected by the food matrix and its processing. A good example is the processing of cereal matrix, which contains higher concentrations of bound phenolic acids (1300-1400 mg/kg FW in whole wheat and rye flour, $>4000 \mathrm{mg} / \mathrm{kg} \mathrm{FW}$ in wheat and rye bran) compared to their free forms $(<20 \mathrm{mg} / \mathrm{kg}$ FW) [11]. Many preliminary processing techniques remove phenolic acids or increase the amount of free phenolic acids in cereal food products. Dehulling reduced the total content of phenolic acids considerably in oat groats, pearled barley, and rye flour [33,34], whereas milling and air-classification increased the content of bound phenolic acids from the levels present in the whole flour [35, 36]. Phenolic acids embedded in the bran matrix can be released during bioprocessing using enzymes alone, such as ferulic acid esterase, xylanases or cellulases [37-40] or by combining enzymes with sourdough fermentation [31, 41-43]. Germination is a traditional means of bioprocessing alone or in combination with dough fermentation with yeast, which enhance the release of free phenolic acids in dough [44, 45].

Bread-making includes several fundamental operations, namely mixing, fermentation and baking, which are indispensable for producing an attractive bread. Fermentation of the dough contributes to an increase in phenolic acids and the mechanism proposed is via the structural breakdown of 
the cell wall matrix by degrading enzymes present in both grains and microbes such as xylanases and esterases [46]. Dough mixing causes an overall decrease in bound ferulic acid, sinapic acid, and caffeic acid in various grains, increasing the amount of free ferulic acid significantly up to fivefold from the initial level [20, 47, 48]. Yu and Beta [49] found an increase (103-109\%) in the contents of free ferulic acid and $p$-hydroxybenzoic acids in bread crust after baking in the oven, suggesting that some free phenolic acids are thermally labile. However, in the crumb, the levels of bound phenolic acids increased instead [49]. Other thermal processes include extrusion and infrared heating, which may have a varying effect on the content of free phenolic acids. For example, extrusion with high temperature and pressure increased the content of free phenolic acids in pearled barley by $72 \%$, whereas milder conditions by infrared heating and flaking of the same material did not have any effect [33]. In vitro models have been used to study the impact of bioprocessing on the release of phytochemicals including phenolic acids [50-52].

There are only few in vivo studies and on the degree of processing, including animal studies $[53,54]$ and human interventions [21, 22, 55], all of which showed a variation in the urinary excretion of HCAs or their metabolites. Bioprocessing showed a significant role on the bioavailability of ferulic acid only, while $p$-coumaric acid contents did not change neither in whole grain rye nor in whole-grain wheat $[21,22,56,57]$. Table 1 gives examples of selected food items, their phenolic acid consumption levels, and bioavailability as HCAs after deconjugation before analysis (Table 1; $[21,22,55])$.

In conclusion, to assess the dietary intake of phenolic acids and their conjugates, accurate and wide-scale analysis is crucial to determine the diversity and the contents of compounds in food stuffs. For non-traditional wheat species, such as einkorn, emmer, spelt, and pigmented cultivars, a significant gap remains concerning the release properties of their matrix; these crops might deserve a more substantial role in human nutrition, potentially affecting health responses.

\section{Metabolism of phenolic acids}

When phenolic acids are consumed, they undergo substantial metabolism by tissues, organs and colonic microbiota. In this section, the metabolic routes and interplay between the host and residing microbiota are discussed.

Free phenolic acids can be released from food and beverage matrices in the stomach, the muscles of which reduce food particle size and further enhance the release of phenolic compounds and their absorption [58-60]. Table 1 shows the impact of food matrix in the bioavailability: the absorption of phenolic acids from beverages (cranberry juice, coffee, and yerba mate [61-63]) occurs at a higher extent than from solid food matrices (whole grain cereals) (Table 1). Since a high proportion of HCAs is conjugated or bound to dietary fibre matrix, the majority of these compounds reach the colon, and their bioavailability requires the activity of degradation enzymes in intestinal tissues and microbiota [64-68]. Hydrolysis by intestinal or microbial esterases is probably the major route for release of free HCAs from their conjugation in vivo. After deconjugation, the released phenolic acids can be absorbed across the gastrointestinal barrier and enter the peripheral blood circulation [65].

\section{Metabolism by the host}

Absorbed dietary phenolic acids can be perceived by the body as xenobiotic substances and thus they undergo metabolism to facilitate their removal. Xenobiotic metabolism is a multi-organ process, starting in the upper intestinal epithelia and largely continuing in the lower intestine and liver, as well as in peripheral tissues, such as kidneys and adipose tissue. Hepatic enzymes transform molecules by adding or removing hydroxyl groups (phase I) and conjugating them to other molecules (phase II) to increase their water solubility, thus enhancing their excretion in urine. HCAs undergo glucuronidation and/or sulfation, or are oxidized into benzoic acid derivatives, which are finally glycinated into hippuric acid derivatives [1, 69-71]. Table 1 shows maximal concentrations in plasma $(\mathrm{nM})$ and total 24-h urinary excretion as $\mathrm{mg}$ or as nmol of hepatic metabolites of HCAs, which in some studies are deconjugated before analysis [21, 22, 29, 55] and expressed as free phenolic acids, and in others as sulfate and glucuronide conjugates of ferulic acid.

Xenobiotic metabolism is also subjected to individual responses. The enzymes of detoxification, responsible for phase I and II metabolism and phase III transport [72], may be expressed differently upon nutritional stimuli or genetic polymorphisms, causing interindividual variation [73]. One of the major enzyme systems that handles the capacity of an organism to metabolize xenobiotics, are the cytochrome P450 monooxygenases [74]. The expression of CYP2D6 (debrisoquine hydroxylase) and CYP2C19 (mephenytoin hydroxylase) genes may vary up to 1000 fold between individuals and thus lead to individuals considered as poor or extensive metabolizers [73]. Genetic polymorphisms have been described for most drug metabolizing enzymes, such as genes involved in acetylation and oxidation. Slow acetylator phenotypes occur in habitants of Europe and North America (40-70\%), while in Asia Pacific, only $10-30 \%$ of the residents are slow acetylators. 
The cytosolic $N$-acetyltransferase in the liver, responsible for the transfer of acetate from acetyl-CoA to the substrate, is encoded by the NAT1 and NAT2 genes. The slow acetylator phenotype is related to a reduction of 10-20\% of NAT2 protein in the liver, due to the existence of NAT2 alleles with decreased functionality [73].

\section{Metabolism by gut microbiota}

The role of gut microbiota in the biotransformation of phytochemicals, phenolic acids among them, is widely acknowledged, causing the formation of food-derived metabolites in the circulation and excreted in the urine. Table 1 shows some examples of the analysed microbial metabolite profiles from human interventions. However, in vivo results show large interindividual variation, and when the metabolite profile contains many different metabolites with high interindividual variation, any differences between the study groups become more difficult to detect.

Since the biotransformation capacity of the gut microbiota is extensive, in vitro studies have attempted to identify colonic metabolites of phenolic acids. Braune et al. [75] studied the in vitro anaerobic degradation of isolated ferulic acid dimers, 8-O-4-diferulic acid $(\mathrm{C}-\mathrm{O}-\mathrm{C}$-bond) and 5-5-diferulic acid (C-C-bond), using human faecal suspension as an inoculum. They showed that the biotransformation of $\mathrm{C}-\mathrm{O}-\mathrm{C}$-dimers started with the release of ferulic acid (which was converted to hydroxylated phenylpropionic acids) and 3-(4-hydroxy-3-methoxyphenyl)pyruvic acid (which was a precursor to hydroxylated phenylacetic and phenyllactic acids) [75]. The further formation of 3-(3-hydroxyphenyl)propionic acid and its subsequent dehydroxylation to 3-phenylpropionic acid has been shown for ferulic acid and caffeic acid derivatives [57, 76]. In addition, $\mathrm{C}-\mathrm{C}$-bonded 5-5-diferulate had conversions in the attached units without degradation of the $\mathrm{C}-\mathrm{C}$-bond. Among these conversions were series of demethylations and double bond reductions, which resulted in different combinations of two moieties of caffeic acid, dihydrocaffeic acid (3-(3',4'dihydroxyphenyl)propionic acid), ferulic acid or dihydroferulic acid (3-(3'-methoxy-4'-hydroxyphenyl)propionic acid) attached with the $\mathrm{C}-\mathrm{C}$ bond [75].

The formation of vanillic acid has been suggested to occur in the colon from the main microbial metabolite of ferulic acid, dihydroferulic acid, by $\beta$-oxidation [50, 63]. Ferulic acid can also be degraded to caffeic acid and by reduction to $p$-coumaric acid and cinnamic acid. The $\beta$ - or $\alpha$-oxidation of the aliphatic side chain leads to the accumulation of benzoic acid derivatives that is perhaps the most common intermediate of anaerobic degradation [77-79]. Figure 3 shows also examples of the microbial metabolites, phenylpropionic or phenylacetic acids with different patterns of substitution. It is worthy of a note that benzoic acid derivatives, including hydroxybenzoic acids and their glycinated hepatic metabolites, hippuric acids, are a substantial part in the circulating and excreted metabolite profile, not only of phenolics acids, but also main dietary flavonoids [12].

It is difficult to distinguish the actions of liver from those of the colon without studying the metabolism using in vitro colon and hepatic models, since in vivo studies show their concerted action and the impact of enterohepatic circulation. Human primary hepatocytes are capable of converting phenylpropionic acid to ferulic acid, indicating the presence of post-colonic hepatic metabolites and returning the structural transformation back to original precursor structures [80]. Enterohepatic circulation has shown to contribute to the low diurnal variation of the colonic metabolite concentrations in the blood [81, 82], and also contributing to their long residence time. Pharmacokinetic studies have shown that microbial phenolic acid metabolites have a $24-48 \mathrm{~h}$ residence time in the bloodstream after a single dose of their parent compounds [83, 84]. Phenolic acids are excreted in urine mainly in their free form [83], but it is possible that liver has a role in formation of the post-colonic metabolites [80]. Phenolic acid and phenolic acid microbial metabolite levels in urine are on low or high micromolar level [85], whereas in plasma they range from low to high-nanomolar concentrations $[12,84,86]$. In peripheral tissues, the concentrations can be anticipated to be even lower.

Figure 3 shows benzoic acid derivatives and HCAs after reduction of the double bond in the side chain and conversion to dihydroferulic acid derivative $[63,87]$ and also dihydrocaffeic acid [61, 62], which can be expressed also as phenylpropionic acid derivatives, indicating microbial metabolism. It is noteworthy that HCA metabolites are shared with those of flavonoids and can together have a bigger impact on in human body as a pool of metabolites [80, 85]. As the metabolites described above and their hepatic conjugates are found in plasma and urine, they circulate through the body and may exhibit both local and systemic effects.

In conclusion, interindividual variation is affected by several sites of metabolism, tissues and the intestinal microbiota, causing a diverse metabolite profile. The overall metabolite pool, which circulates in the body, mediates the health benefits of a diet, which may be difficult to attribute to a single food item, study group, or compound class due to high individual variation and interlinked metabolic pathways. The ecology of gut microbiota and variation of the functional genes of the microbes may have a role in interindividual variability in the circulating metabolites and in their health benefits. 


\section{Health benefits related to intake of phenolic acids}

The potential preventive effect of HCAs on several chronic diseases has been widely reviewed in the recent years. HCA derivatives, in particular chlorogenic acids, have been shown to exert health benefits in the management of obesity, cardiovascular diseases, type 2 diabetes mellitus, and metabolic syndrome [2, 88-92], while some antioxidant and neuroprotective effects have also been reported [93-95]. Nevertheless, current evidence is still inconsistent and insufficient to support robust health claims, mostly because the co-occurrence of other plant bioactives (e.g., caffeine and hydroxyhydroquinone in coffee, fibre in wholegrain products, and flavonoids in berries and fruits) in the main dietary sources of HCAs hinders the elucidation of the putative health benefits exerted by these compounds. Moreover, the interindividual variability in the physiological response to consumption of HCAs is almost unknown for most of the biomarkers of cardiometabolic health [96].

HCAs have shown a series of biological activities related to the prevention of cardiovascular diseases, diabetes, and metabolic syndrome in cell and animal studies [2, 89-92, 97-99], but evidence in humans is rather limited. HCAs may enhance cardiovascular health by exerting blood pressurelowering effects and by acutely improving the endothelial function [89, 100, 101]. Some studies suggest that chlorogenic acids may cause significant reductions in systolic and diastolic blood pressure [100, 102, 103], but other studies have instead reported a lack of significant blood pressure reduction [104-106]. The differences could be attributed to the antihypertensive effects of chlorogenic acids only occurring in subjects with mild hypertension and not in normotensives [88, 107]. Moreover, the decrease in blood pressure upon consumption of caffeoylquinic acids from coffee could be inhibited by the presence of hydroxyhydroquinone in brewed coffee. Hydroxyhydroquinone is generated during the roasting of coffee beans, and it is a compound to which prohypertensive effects have been attributed [104]. In addition, dose-response effects of HCAs on blood pressure are not clear [88]. These controversies and lack of robust evidence make the development of health claims or guidelines on the effects of HCA-rich diet on reduced blood pressure extremely difficult.

The acute effects of HCAs on endothelial function are also contradictory. While some human studies indicated a lack of effect of $400 \mathrm{mg}$ of chlorogenic acid (5-caffeoylquinic acid) or coffee containing different amounts of HCAs on flowmediated dilation (FMD) [106, 108], a recent intervention trial by Ward et al. [105] in healthy men and women reported significant effects of chlorogenic acid, at doses of 450 and $900 \mathrm{mg}$, on mean post-ischaemic FMD response. To further complicate the picture, in a similar study conducted only in healthy men, Mills et al. [101] observed improvements in vascular function after pure chlorogenic acid intake, but only at $450 \mathrm{mg}$ and not at $900 \mathrm{mg}$ intake level. Interestingly, these authors also investigated the impact of coffee intake, matching for caffeine, but differing in the content in chlorogenic acids ( 89 and $310 \mathrm{mg}$ ), on FMD response. A bi-phasic FMD response was observed regardless of the intake level, closely in concomitance with the appearance of HCA metabolites in plasma [101]. One of these metabolites peaking in plasma in parallel to the vascular function improvement was ferulic acid 4'-O-sulfate [101], which has recently demonstrated to elicit a concentration-dependent vasorelaxing effect ex vivo [109]. Therefore, further studies are needed to establish a dose-response relationship and to determine the molecular species and their adequate plasma levels to demonstrate the FMD response.

Regarding body weight, Thom observed that the consumption of chlorogenic acid-enriched instant coffee in overweight subjects for 12 weeks significantly reduced body mass and body fat when compared with the use of normal instant coffee [110]. Slight changes in weight were also observed in mildly hypertensive adults when testing coffees deprived of hydroxyhydroquinone and containing different amounts of chlorogenic acids for 4 weeks [107]. On the contrary, chlorogenic acid-rich coffee consumed daily for 4 weeks did not lead to a significant body weight reduction in pre-obese [111] and healthy subjects [112]. An effect of chlorogenic acid consumption on body mass index (BMI) was observed by Watanabe et al. [102] in patients with mild hypertension.

Other biomarkers related to cardiometabolic health have been less investigated. A study reported that the lipid profile of healthy adults did not change after a daily consumption of $400 \mathrm{ml}$ of coffee containing a medium (420 mg) or high $(780 \mathrm{mg}$ ) content of HCAs for 8 weeks [106]. Another trial, which controlled the caffeine intake, indicated that the consumption of coffees containing different amounts of chlorogenic acids attenuated the effects of short-term fructose-induced liver insulin resistance in healthy men [113]. Ochiai et al. [104] showed that coffee chlorogenic acids might decrease urinary isoprostane levels, suggesting a reduced oxidative stress in mild hypertensive Japanese adults with vascular failure and not taking any antihypertensive drugs. The same effect, lowered isoprostane levels, was found in subjects suffering from metabolic syndrome symptoms and using polyphenolrich diet for 8 weeks, showing increased urinary levels of microbial phenolic acid metabolites, which are shared by the HCAs [85, 114]. Therefore, it may be difficult to draw conclusions on the role of a single compound group, such as HCAs in systemic disorders such as lipid metabolism, glucose metabolism, insulin resistance, and inflammation 
based on the limited insights achieved so far in controlled human studies in chronic conditions. However, currently, a systematic review and meta-analysis of randomized controlled trials is being carried out to shed light on the interindividual variability in response to the impact of HCAs on cardiometabolic biomarkers [115]. This work will possibly help to better understand the protective features of HCAs in different population subgroups, but further ad hoc designed clinical trials are required, in our opinion, to tackle the health benefits of HCAs.

Acute studies dealing with postprandial responses seem to indicate that chlorogenic acid intake may attenuate early glucose absorption and insulin response $[116,117]$ and that this effect does not seem to be mediated by incretin hormones (glucagon-like peptide-1, GLP-1, and glucosedependent insulinotropic polypeptide, GIP) in overweight men [118]. In another study, daily consumption of $329 \mathrm{mg}$ of coffee chlorogenic acids increased postprandial fat utilization in healthy humans [112], mainly when hydroxyhydroquinone was not present in the brew [119].

The chemopreventive properties of HCAs have been evaluated mainly in animal and cell models [91]. In humans, the main insights in the chemopreventive activity of HCAs come from observational studies indicating, for instance, an inverse association of wholegrain phenolics with the incidence of colorectal cancer [120], however, results from these studies are affected by several confounding factors, the first being the practical impossibility to fully adjust for fibre intake. Moreover, it has been suggested that chlorogenic acids in coffee may play a role in protecting DNA integrity [121] and in the induction of chemopreventive phase II enzymes via the Nrf2/antioxidant-response element (ARE) detoxifying pathway [122]. This latter effect could vary significantly among individuals, due to the existence of genetic polymorphisms in the $\mathrm{Nrf2}$ gene [122].

The biological properties of HCAs in the framework of brain function have been scarcely investigated [93, 95]. To date, only a few studies have been conducted in humans to address the cognitive and mood effects associated to their intake. In an acute study in healthy elderly subjects, Cropley et al. [123] reported that coffee chlorogenic acids may modulate brain function by improving some mood and behavioural processes. In another study, using a decaffeinated green coffee blend and pure 5-caffeoylquinic acid, Camfield et al. [124] assessed several cognitive and mood outcomes and concluded that the improvements observed in mood, but not in cognitive function, could be partially attributable to coffee chlorogenic acids. Further work is required to tackle the effects of HCAs consumption on human brain function.

\section{Interindividual variability in health responses}

The interindividual variability in health responses to phenolic acid-rich foods has been scarcely studied, although some insights have been gained. A polyphenol-rich diet was shown to significantly reduce the markers of dyslipidaemia (triglycerides and VLDL) and oxidative stress (8-isoprostane urinary excretion) in 86 overweight or obese individuals despite of a large variability in the responses [114]. However, the variability was not associated with a specific factor, nor was the diet assessed for the intake of particular classes of polyphenols, including phenolic acids and flavonoids. Artichoke leaf extract, containing mainly HCAs (chlorogenic acid, cynarin, and caffeic acid), sesquiterpene lactones, and flavonoids (e.g., luteolin), decreased LDL-C levels only in men with a certain genotype of Taq IB in the CETP gene (cholesteryl ester transfer protein) [125]. The effect is likely attributable to the (poly)phenols present in artichoke, but the contribution of phenolic acids remains unclear, since both chlorogenic acid and luteolin can inhibit LDL oxidation in vitro [126]. In another RCT study by Gavrieli et al., coffee delayed the postprandial glucose response more in females and overweight or obese participants compared to men and participants with normal weight, respectively [127]. A randomized crossover study, where coffee containing green and roasted beans was consumed by 52 volunteers, found decreased levels of lipid markers (LDL-C, VLDL-C, and triglycerides) only in the hypercholesterolemic group $(n=27)$, but not in the normocholesterolemic one $(n=25)$ [128]. The same research group also found a decrease in some markers of metabolic syndrome (blood glucose, insulin resistance, and triglycerides) after consumption of green/roasted coffee blend only in hypercholesterolemic subjects [129]. However, decaffeinated coffee was not used as a control in any of these studies to determine the effect of other phytochemicals in coffee, which includes high amounts of phenolic acids but also caffeine, trigonelline and diterpenes [130]. When the effect of both regular and decaffeinated espresso was studied on the elastic properties of the aorta and wave reflections, a stronger response was observed among non-habitual coffee drinkers compared to habitual drinkers after the intake of both types of coffee [131]. No difference was seen after receiving caffeine alone, suggesting that the phenolic acids in coffee may be responsible for the interindividual variability in the responses, although the effects of other phytochemicals cannot be excluded. Further evidence of the role of coffee phenolic acids was obtained by Jokura et al., who gave coffee polyphenol extract, consisting mostly of chlorogenic acids, to 19 male volunteers [132]. A significantly increased level of GLP-1, involved in anti-diabetic and beneficial cardiovascular effects, was observed only in individuals with 
a lower insulinogenic index. However, only the levels of chlorogenic acids were measured from the extract, and thus the contribution of other phytochemicals (except caffeine) to the effect cannot be ruled out.

In conclusion, although HCAs have been linked with promising effects associated to human health promotion and disease prevention, the current evidence of their role is far from being robust and conclusive, and more research is needed. The variability in the individual health responses to phenolic acids seems to be related to the metabolic status, gender, dietary habits, and genetic polymorphisms, but the contribution of other dietary bioactives cannot be dismissed. Further studies should be designed, taking into account the potential confounding effects of other plant phytochemicals and their metabolites present in concomitance with HCAs, and the heterogeneity in the responsiveness to HCA consumption should be more carefully investigated.

\section{Which factors are relevant in the interindividual variation?}

The scenario is complex when attempting to characterise the large interindividual variability in the metabolism and response of food phytochemicals, such as HCAs, HBAs and polyphenols sharing partially the same microbial metabolites. Various factors are relevant: controlling the diet of the intervention (contents of the phytochemicals in beverages or food matrices, effects of processing on their release), gut microbial ecology and genetics, and enzymatic plasticity of the host (phase I and II metabolic enzymes, and phase III transporters) and those of the microbiome. Furthermore, beyond the bioactive phytochemical component at study, dietary habits, lifestyle, geographical and other environmental factors influence the biological effect on health and disease state (Fig. 2).

It is clear that free-living people do not eat only single foods, and they seldom obey a controlled diet for a long period of time. However, phenolic acids may contribute to the dietary intake of polyphenols to a substantial degree. As shown in Table 1, the phenolic acid content of polyphenolrich diet represent almost half of the total polyphenol intake. The metabolic routes of HCAs have been recently elucidated to some extent, and the effect of food processing on the HCAs may cause variation [51, 63-66]. Still, we need to acknowledge that processing, affecting indirectly the bioavailability of phenolic acids, has a limited impact on the interindividual variability, if we consider the whole dietary consumption.

Human interventions, sometimes including a low number of subjects (Table 1), have observed biomarkers of phenolic acid intake or correlations between the intake and health

Factors influencing interindividual variability of consumption of phenolic acid-rich foods

Food composition

- Variety of plant species (diet as a whole)

- Cultivation conditions

- Harvesting and storage

- Food (pre-)processing

Nutritional aspects

- Meal preparation \& matrix

- Time of consumption

- Dietary habits

How to address interindividual variability of phenolic acids (What kind of experiments do we need to perform to better address interindividual variation?)

- In vitro studies of gut biotransformations of phenolic acids and the bioactivity and metabolic fate of the metabolites in relevant cellular models

- Combining in vitro and in vivo studies

- Food metabolome characterization (compounds, classes, etc.)

- Comparison of controlled (pre-)clinical trials of pure compounds vs. compound-rich foods with detailed dietary and lifestyle records

- Sufficient number of participants to increase statistical power and to determine responders and non-responders

- Considering the detection limit and identification of significant differential metabolites in various matrices

Fig. 2 Factors influencing the interindividual variability related to consumption of phenolic acid-rich foods and recommendations for future research. The factors with major impact according to current knowledge are underlined

benefits. The subtle differences are discussed with regard to other confounding factors or components. The observed correlations do not represent causality, and thus a better understanding of the gut-host interplay and microbiome biochemistry is becoming highly relevant. The reversible interaction between the diet, the host and the microbiome, and their consequent synergistic effects on health is a challenge to tackle. Because of this three-way interplay, it is important to understand which microbial species correlate with the phenolic metabolites produced at individual level. Microbiological studies, and especially those dealing with ecological communities of microbiomes, including genomescale models, studying the functional genome of the microbiome, could explain partly interindividual variation of the microbial metabolites [133].

Do we understand the microbial metabolism to a full degree? Microbial transformations of ferulic acid have been described in various environments beyond the human gut microbiota, with concurrent intermediates to those found in faecal matter [134]: oxidation or reduction of the side chains, 
European Journal of Nutrition (2020) 59:1275-1293

1287

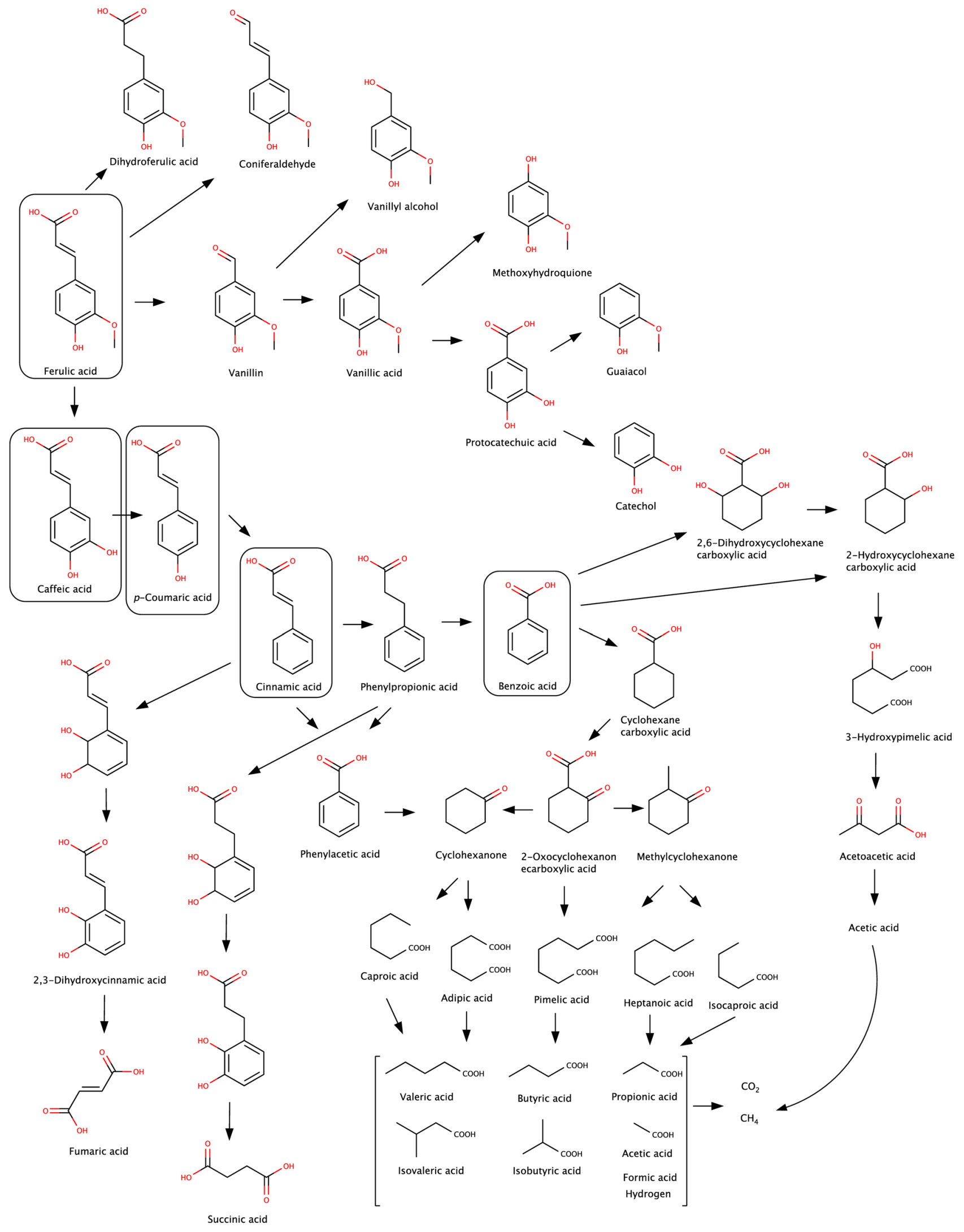

Fig. 3 Major pathways of the microbial anaerobic degradation of ferulic acid, caffeic acid and $p$-coumaric acid. The pathways are connected to hydroxybenzoic acids and amino acids

Springer 
leading to coniferaldehyde and vanillyl alcohol or dihydroferulic acid; cleavage of the side chain, forming vanillin and eventually vanillic acid via the oxidation of the aldehyde group; and finally, the formation of guaiacol and protocatechuic acid as common intermediates (Fig. 3). Benzoic acid (and benzoyl-CoA, which is readily formed by benzoate CoA ligase) is a kernel intermediate from the anaerobic degradation of aromatic compounds [78, 135]. Therefore, benzoic acid can also be a general degradation product from aromatic compounds, such as vanillin, $p$-cresol, phenol, aniline, aromatic amino acids such as phenylalanine, and polyphenol flavonoids. Benzoic acid, the simplest of all aromatic acids, can be further de-aromatized (partially or completely), forming cyclohexane carboxylic acid and cyclohexanone. Hydroxylated forms of cyclohexane carboxylic acid have also been detected from anaerobic degradation of aromatic compounds. The anaerobic metabolism culminates in ring opening and aliphatic compounds such as caproic acid, adipic acid, pimelic acid, and their hydroxylated forms can be formed [77, 136, 137]. Ultimately, short-chain fatty acids (valeric acid, butyric acid, propionic acid, and acetic acid, and their respective CoA conjugates) accumulate [79]. Nevertheless, despite this key information, the impact of anaerobic microbial metabolism of phenolic acids on interindividual variability is limited and poorly known.

The microbial and endogenous metabolism of phenolic acids has proven to be complex and interlinked, and future studies may reveal additional intermediary or end metabolites, which may have synergistic effects on host. The increased number of bioinformatic tools, including mapping and prediction of biochemical pathways with databases, such as the PhenolExplorer [138], the Atlas of Biochemistry [139], and the biocatalysis/biodegradation database with curated information on environmental degradation of pure compounds [79], could help in the identification of the various still unknown substances. Those compounds may be difficult to connect with phytochemicals because their origin may be challenging to be distinguished from dietary fibre carbohydrates, proteins, and amino acid degradation, which exceed 100-1000-fold the contribution of any non-nutrient phytochemicals in the diet. Therefore, it is worthwhile to focus on the major metabolites that can be identified from hepatic or colonic conversions using in vitro models, and those that can be detected from the body fluids, e.g., plasma and urine. It is worth of a note that the gut microbial metabolism also reduces the chemical complexity of the metabolites, as larger structures, such as polyphenols, are degraded into smaller, simpler structures of microbial phenolic acids, which are the same as those formed from HCAs and benzoic acid derivatives of the diet, as indicated in Table 1. Nevertheless, the large number of metabolites emerging from even one single component enhances the impact of interindividual variation, since the minor metabolites cannot be distinguished as significantly differing components from the control groups.

In vivo and in vitro research should go hand in hand to understand the efficacy of bioactive compounds, and mechanisms involved, to assess health benefits and define recommendations. The pool of circulating metabolites could be related to shorter (hepatic metabolites) or longer (microbial metabolites) residence times and a synergy of these metabolites may cause the effect on health. Regarding not only interindividual variability but also intra individual variability, more research is warranted on gene variants showing how variability in enzymes of liver and the functionality of colonic microbial community affect the levels of phenolic acid metabolites. The variability in the genes and enzymatic activities of the complex system of xenobiotic metabolism is also a large contributor to how an individual handles phenolic acids and the metabolic fate of the compounds. Here, research on drugs proves to be crucial to characterise enzymes and identify genetic polymorphisms, affecting the ability of the host to convert the circulating metabolites also from the diet. Therefore, scientific communities of drug and food research could collaborate to learn more from each other and potential synergistic effects of the diet and drugs on the host metabolism.

Conventionally, human interventions studying health benefits and those studying the metabolite profiles after consumption of phenolic acid-rich foods have been performed separately. Furthermore, the studies are objected to a limited number of food items, and with limited number of subjects, which results in subtle differences between study groups. Only seldom do studies combine the two approaches and approach the whole recommendable diet $[85,114]$. It is also a fact that results from intervention studies are only presented as averages and standard deviations or means and interquartile ranges (IQR; ranges of middle 50\%), which exhibit the large variations, but make the results difficult to interpret.

Even a "perfect" study design cannot eliminate or completely tackle individual variation. Would it be possible and acceptable to change the approach to handle the data? The responders and non-responders of the observed health effect could be separated, and the affecting factors could be studied analysing the biomarkers of intake (including the host-derived and microbial metabolites) and expression of genes. On the other hand, genetic polymorphism could be the starting point of a study, followed by investigating the metabolism and health responses in a synergistic manner. Thus, health responses could be crossreferenced with metabolite profiles, gene variants, diet, exercise, or other lifestyle factors. This has been used in medical research in case-control studies. Could we adopt new approaches of designing experiments or handling the 
data to help overcome the interindividual variation? Could artificial intelligence and collection of big data help in identifying critical factors? There is a need for a thorough discussion on how the limiting factor, interindividual variability, could be turned into an asset in an ethical way to better understand and utilize personalized nutrition and the impact of the complete recommended diet on health.

Acknowledgements Open access funding provided by University of Eastern Finland (UEF) including Kuopio University Hospital. All authors are participants of the EU-funded COST Action FA1403 POSITIVe (Interindividual variation in response to consumption of plant food bioactives and determinants involved).

\section{Compliance with ethical standards}

Conflict of interest The authors have no conflict of interests.

Open Access This article is distributed under the terms of the Creative Commons Attribution 4.0 International License (http://creativeco mmons.org/licenses/by/4.0/), which permits unrestricted use, distribution, and reproduction in any medium, provided you give appropriate credit to the original author(s) and the source, provide a link to the Creative Commons license, and indicate if changes were made.

\section{References}

1. Zhao Z, Moghadasian MH (2008) Chemistry, natural sources, dietary intake and pharmacokinetic properties of ferulic acid: a review. Food Chem 109(4):691-702. https://doi.org/10.1016/j. foodchem.2008.02.039

2. El-Seedi HR, El-Said AMA, Khalifa SAM, Göransson U, Bohlin L, Borg-Karlson AK, Verpoorte R (2012) Biosynthesis, natural sources, dietary intake, pharmacokinetic properties, and biological activities of hydroxycinnamic acids. J Agric Food Chem 60(44):10877-10895. https://doi.org/10.1021/jf301807g

3. Lafay S, Gil-Izquierdo A (2008) Bioavailability of phenolic acids. Phytochem Rev 7(2):301

4. Herrmann K, Nagel CW (1989) Occurrence and content of hydroxycinnamic and hydroxybenzoic acid compounds in foods. Crit Rev Food Sci Nutr 28(4):315-347

5. Tomás-Barberán FA, Clifford MN (2000) Dietary hydroxybenzoic acid derivatives-nature, occurrence and dietary burden. J Sci Food Agric 80(7):1024-1032

6. Wada L, Ou B (2002) Antioxidant activity and phenolic content of Oregon caneberries. J Sci Food Agric Chem 50(12):3495-3500

7. De Vasconcelos MDCBM, Bennett RN, Rosa EA, Cardoso JVF (2007) Primary and secondary metabolite composition of kernels from three cultivars of Portuguese chestnut (Castanea sativa Mill.) at different stages of industrial transformation. J Agric Food Chem 55(9):3508-3516

8. Tomás-Barberan FA, Espín JC, García-Conesa MT (2009) Bioavailability and metabolism of ellagic acid and ellagitannins. In: Quideau S (ed) Chemistry and biology of ellagitannins: an underestimated class of bioactive plant polyphenols. World Scientific, pp 273-297. https://doi.org/10.1142/6795

9. El Gharras H (2009) Polyphenols: food sources, properties and applications-a review. Int J Food Sci Technol 44(12):25122518. https://doi.org/10.1111/j.1365-2621.2009.02077.x
10. Farah A, de Paulis T, Trugo LC, Martin PR (2005) Effect of roasting on the formation of chlorogenic acid lactones in coffee. J Agric Food Chem 53(5):1505-1513. https://doi.org/10.1021/ jf048701t

11. Mattila P, Pihlava JM, Hellström J (2005) Contents of phenolic acids, alkyl- and alkenylresorcinols, and avenanthramides in commercial grain products. J Agric Food Chem 53(21):82908295. https://doi.org/10.1021/jf051437z

12. Del Rio D, Rodriguez-Mateos A, Spencer JPE, Tognolini M, Borges G, Crozier A (2013) Dietary (poly)phenolics in human health: structures, bioavailability, and evidence of protective effects against chronic diseases. Antioxid Redox Signal 18(14):1818-1892

13. Gawel R, Schulkin A, Smith PA, Waters EJ (2014) Taste and textural characters of mixtures of caftaric acid and grape reaction product in model wine. Aust J Grape Wine Res 20(1):25-30. https://doi.org/10.1111/ajgw.12056

14. Hayasaka Y, Black CA, Hack J, Smith P (2017) Structural characterization of reaction products of caftaric acid and bisulfite present in a commercial wine using high resolution mass spectrometric and nuclear magnetic resonance techniques. Food Chem 230:99-107. https://doi.org/10.1016/j.foodchem.2017.03.005

15. Clifford MN, Knight S, Surucu B, Kuhnert N (2006) Characterization by LC-MS(n) of four new classes of chlorogenic acids in green coffee beans: dimethoxycinnamoylquinic acids, diferuloylquinic acids, caffeoyl-dimethoxycinnamoylquinic acids, and feruloyl-dimethoxycinnamoylquinic acids. J Agric Food Chem 54(6):1957-1969. https://doi.org/10.1021/jf060 1665

16. Jaiswal R, Patras MA, Eravuchira PJ, Kuhnert N (2010) Profile and characterization of the chlorogenic acids in green Robusta coffee beans by LC-MS(n): identification of seven new classes of compounds. J Agric Food Chem 58(15):8722-8737. https:// doi.org/10.1021/jf1014457

17. Ludwig IA, Clifford MN, Lean MEJ, Ashihara H, Crozier A (2014) Coffee: biochemistry and potential impact on health. Food Funct 5(8):1695-1717. https://doi.org/10.1039/c4fo00042k

18. Ludwig IA, Mena P, Calani L, Cid C, Del Rio D, Lean MEJ, Crozier A (2014) Variations in caffeine and chlorogenic acid contents of coffees: what are we drinking? Food Funct 5(8):17181726. https://doi.org/10.1039/c4fo00290c

19. Gómez-Juaristi M, Martínez-López S, Sarria B, Bravo L, Mateos $\mathrm{R}$ (2018) Absorption and metabolism of yerba mate phenolic compounds in humans. Food Chem 240:1028-1038

20. Angelino D, Cossu M, Marti A, Zanoletti M, Chiavaroli L, Brighenti F, Del Rio D, Martini D (2017) Bioaccessibility and bioavailability of phenolic compounds in bread: a review. Food Funct 8(7):2368-2393. https://doi.org/10.1039/c7fo00574a

21. Lappi J, Aura A-M, Katina K, Nordlund E, Kolehmainen M, Mykkänen H, Poutanen K (2013) Comparison of postprandial phenolic acid excretions and glucose responses after ingestion of breads with bioprocessed or native rye bran. Food Funct 4(6):972-981

22. Mateo Anson N, Aura AM, Selinheimo E, Mattila I, Poutanen $\mathrm{K}$, van den Berg R, Havenaar R, Bast A, Haenen GR (2011) Bioprocessing of wheat bran in whole wheat bread increases the bioavailability of phenolic acids in men and exerts antiinflammatory effects ex vivo. J Nutr 141(1):137-143. https://doi.org/10.3945/ jn. 110.127720

23. Vitaglione P, Napolitano A, Fogliano V (2008) Cereal dietary fibre: a natural functional ingredient to deliver phenolic compounds into the gut. Trends Food Sci Technol 19(9):451-463. https://doi.org/10.1016/j.tifs.2008.02.005

24. Heimler D, Vignolini P, Dini MG, Vincieri FF, Romani A (2006) Antiradical activity and polyphenol composition of local 
Brassicaceae edible varieties. Food Chem 99(3):464-469. https ://doi.org/10.1016/j.foodchem.2005.07.057

25. Moreno DA, Pérez-Balibrea S, Ferreres F, Gil-Izquierdo A, García-Viguera C (2010) Acylated anthocyanins in broccoli sprouts. Food Chem 123(2):358-363. https://doi.org/10.1016/j. foodchem.2010.04.044

26. Taveira M, Pereira DM, Sousa C, Ferreres F, Andrade PB, Martins A, Pereira JA, Valentao P (2009) In vitro cultures of Brassica oleracea L. var. costata DC: potential plant bioreactor for antioxidant phenolic compounds. J Agric Food Chem 57(4):12471252. https://doi.org/10.1021/jf803496x

27. Bunzel M (2010) Chemistry and occurrence of hydroxycinnamate oligomers. Phytochem Rev 9(1):47-64. https://doi. org/10.1007/s11101-009-9139-3

28. Bunzel M, Ralph J, Marita JM, Hatfield RD, Steinhart H (2001) Diferulates as structural components in soluble and insoluble cereal dietary fibre. J Sci Food Agric 81(7):653-660. https://doi. org/10.1002/jsfa.861

29. Kern SM, Bennett RN, Mellon FA, Kroon PA, Garcia-Conesa M-T (2003) Absorption of hydroxycinnamates in humans after high-bran cereal consumption. J Agric Food Chem 51(20):6050-6055

30. Bunzel M, Ralph J, Kim H, Lu F, Ralph SA, Marita JM, Hatfield RD, Steinhart H (2003) Sinapate dehydrodimers and sinapateferulate heterodimers in cereal dietary fiber. J Agric Food Chem 51(5):1427-1434. https://doi.org/10.1021/jf020910v

31. Hole AS, Rud I, Grimmer S, Sigl S, Narvhus J, Sahlstrom S (2012) Improved bioavailability of dietary phenolic acids in whole grain barley and oat groat following fermentation with probiotic Lactobacillus acidophilus, Lactobacillus johnsonii, and Lactobacillus reuteri. J Agric Food Chem 60(25):6369-6375. https://doi.org/10.1021/jf300410h

32. Mattila P, Hellström J, Törrönen R (2006) Phenolic acids in berries, fruits, and beverages. J Agric Food Chem 54(19):7193-7199

33. Sahlstrøm S, Hole A, Naterstad K, Grimmer S (2010) Effects of commercial processing of barley on levels of phenolic acids and antioxidant activity: role of dietary phenolic acids on activation and inhibition of nuclear factor $\kappa B$. In: Van der Kamp JW, Jones J, McCleary B, Topping D (eds) Dietary fibre: new frontiers for food and health. Wageningen Academic Publishers, Wageningen, pp 415-430

34. Liukkonen K-H, Katina K, Wilhelmsson A, Myllymäki O, Lampi A-M, Kariluoto S, Piironen V, Heinonen S-M, Nurmi T, Adlercreutz H (2003) Process-induced changes on bioactive compounds in whole grain rye. Proc Nutr Soc 62(01):117-122

35. Izydorczyk MS, Symmoms SJ, Dexter JE (2002) Fractionation of wheat and barley. In: Marquart L, Slavin JL, Fulcher RG (ed) Whole-grain foods in health and disease. AACC, St. Paul

36. Newman RK, Newman CW (eds) (2008) Barley processing: methods and product composition. In: Barley for food and health. Wiley, Hoboken, pp 95-132

37. Verardo V, Gómez-Caravaca AM, Marconi E, Caboni MF (2011) Air classification of barley flours to produce phenolic enriched ingredients: comparative study among MEKC-UV, RP-HPLCDAD-MS and spectrophotometric determinations. LWT Food Sci Technol 44(7):1555-1561

38. Donaghy J, Kelly P, McKay AM (1998) Detection of ferulic acid esterase production by Bacillus spp. and lactobacilli. Appl Microbiol Biotechnol 50(2):257-260

39. Topakas E, Vafiadi C, Christakopoulos P (2007) Microbial production, characterization and applications of feruloyl esterases. Process Biochem 42(4):497-509

40. Sancho A, Bartolomé B, Gómez-Cordovés C, Williamson G, Faulds CB (2001) Release of ferulic acid from cereal residues by barley enzymatic extracts. J Cereal Sci 34(2):173-179
41. Koistinen VM, Katina K, Nordlund E, Poutanen K, Hanhineva K (2016) Changes in the phytochemical profile of rye bran induced by enzymatic bioprocessing and sourdough fermentation. Food Res Int 89:1106-1115

42. Moore J, Cheng Z, Su L, Yu L (2006) Effects of solid-state enzymatic treatments on the antioxidant properties of wheat bran. $\mathrm{J}$ Agric Food Chem 54(24):9032-9045

43. Sørensen HR, Meyer AS, Pedersen S (2003) Enzymatic hydrolysis of water-soluble wheat arabinoxylan. 1. Synergy between $\alpha-1$ arabinofuranosidases, endo- $1,4-\beta$-xylanases, and $\beta$-xylosidase activities. Biotechnol Bioeng 81(6):726-731

44. Yang TK, Basu B, Ooraikul F (2001) Studies on germination conditions and antioxidant contents of wheat grain. Int J Food Sci Nutr 52(4):319-330

45. Katina K, Liukkonen KH, Kaukovirta-Norja A, Adlercreutz H, Heinonen SM, Lampi AM, Pihlava JM, Poutanen K (2007) Fermentation-induced changes in the nutritional value of native or germinated rye. J Cereal Sci 46(3):348-355

46. Đorđević TM, Siler-Marinković SS, Dimitrijević-Branković SI (2010) Effect of fermentation on antioxidant properties of some cereals and pseudo cereals. Food Chem 119(3):957-963

47. Abdel-Aal E-SM, Rabalski I (2013) Effect of baking on free and bound phenolic acids in wholegrain bakery products. J Cereal Sci 57(3):312-318

48. Lu Y, Luthria D, Fuerst EP, Kiszonas AM, Yu L, Morris CF (2014) Effect of processing on phenolic composition of dough and bread fractions made from refined and whole wheat flour of three wheat varieties. J Agric Food Chem 62(43):10431-10436

49. Yu L, Beta T (2015) Identification and antioxidant properties of phenolic compounds during production of bread from purple wheat grains. Molecules 20(9):15525-15549

50. Koistinen VM, Nordlund E, Katina K, Mattila I, Poutanen K, Hanhineva K, Aura A-M (2017) Effect of bioprocessing on the in vitro colonic microbial metabolism of phenolic acids from rye bran fortified breads. J Agric Food Chem 65(9):1854-1864

51. Hanhineva K, Aura A-M, Rogachev I, Matero S, Skov T, Aharoni A, Poutanen K, Mykkänen H (2012) In vitro microbiotic fermentation causes an extensive metabolite turnover of rye bran phytochemicals. PLoS One 7(6):e39322

52. Nordlund E, Katina K, Aura A-M, Poutanen K (2013) Changes in bran structure by bioprocessing with enzymes and yeast modifies the in vitro digestibility and fermentability of bran protein and dietary fibre complex. J Cereal Sci 58(1):200-208

53. Hole AS, Kjos NP, Grimmer S, Kohler A, Lea P, Rasmussen B, Lima LR, Narvhus J, Sahlstrøm S (2013) Extrusion of barley and oat improves the bioaccessibility of dietary phenolic acids in growing pigs. J Agric Food Chem 61(11):2739-2747

54. Pekkinen J, Rosa NN, Savolainen O-I, Keski-Rahkonen P, Mykkänen H, Poutanen K, Micard V, Hanhineva K (2014) Disintegration of wheat aleurone structure has an impact on the bioavailability of phenolic compounds and other phytochemicals as evidenced by altered urinary metabolite profile of diet-induced obese mice. Nutr Metab 11(1):1

55. Harder H, Tetens I, Let MB, Meyer AS (2004) Rye bran bread intake elevates urinary excretion of ferulic acid in humans, but does not affect the susceptibility of LDL to oxidation ex vivo. Eur J Nutr 43(4):230-236

56. Anson NM, van den Berg R, Havenaar R, Bast A, Haenen GR (2009) Bioavailability of ferulic acid is determined by its bioaccessibility. J Cereal Sci 49(2):296-300

57. Anson NM, Selinheimo E, Havenaar R, Aura A-M, Mattila I, Lehtinen P, Bast A, Poutanen K, Haenen GR (2009) Bioprocessing of wheat bran improves in vitro bioaccessibility and colonic metabolism of phenolic compounds. J Agric Food Chem 57(14):6148-6155. https://doi.org/10.1021/jf900492h 
58. Scalbert A, Morand C, Manach C, Rémésy C (2002) Absorption and metabolism of polyphenols in the gut and impact on health. Biomed Pharmacother 56(6):276-282

59. Lafay S, Gil-Izquierdo A, Manach C, Morand C, Besson C, Scalbert A (2006) Chlorogenic acid is absorbed in its intact form in the stomach of rats. J Nutr 136(5):1192-1197

60. Zhao Z, Egashira Y, Sanada H (2004) Ferulic acid is quickly absorbed from rat stomach as the free form and then conjugated mainly in liver. J Nutr 134(11):3083-3088

61. Stalmach A, Mullen W, Barron D, Uchida K, Yokota T, Cavin C, Steiling H, Williamson G, Crozier A (2009) Metabolite profiling of hydroxycinnamate derivatives in plasma and urine following the ingestion of coffee by humans: identification of biomarkers of coffee consumption. Drug Metab Dispos. https://doi.org/10.1124/ dmd.109.028019

62. Renouf M, Guy P, Marmet C, Longet K, Fraering A-L, Moulin J, Barron D, Dionisi F, Cavin C, Steiling H (2010) Plasma appearance and correlation between coffee and green tea metabolites in human subjects. Br J Nutr 104(11):1635-1640

63. Feliciano RP, Boeres A, Massacessi L, Istas G, Ventura MR, dos Santos CN, Heiss C, Rodriguez-Mateos A (2016) Identification and quantification of novel cranberry-derived plasma and urinary (poly) phenols. Arch Biochem Biophys 599:31-41. https://doi. org/10.1016/j.abb.2016.01.014

64. Andreasen MF, Kroon PA, Williamson G, Garcia-Conesa MT (2001) Esterase activity able to hydrolyze dietary antioxidant hydroxycinnamates is distributed along the intestine of mammals. J Agric Food Chem 49(11):5679-5684. https://doi. org/10.1021/jf010668c

65. Andreasen MF, Kroon PA, Williamson G, Garcia-Conesa MT (2001) Intestinal release and uptake of phenolic antioxidant diferulic acids. Free Radic Biol Med 31(3):304-314. https:// doi.org/10.1016/s0891-5849(01)00585-8

66. Kroon PA, Faulds CB, Ryden P, Robertson JA, Williamson G (1997) Release of covalently bound ferulic acid from fiber in the human colon. J Agric Food Chem 45(3):661-667. https:// doi.org/10.1021/jf9604403

67. Plumb GW, Garcia-Conesa MT, Kroon PA, Rhodes M, Ridley S, Williamson G (1999) Metabolism of chlorogenic acid by human plasma, liver, intestine and gut microflora. J Sci Food Agric 79(3):390-392. https://doi.org/10.1002/(sici)10970010(19990301)79:3\%3c390:aid-jsfa258\%3e3.0.co;2-0

68. Rondini L, Peyrat-Maillard MN, Marsset-Baglieri A, Fromentin G, Durand P, Tome D, Prost M, Berset C (2004) Bound ferulic acid from bran is more bioavailable than the free compound in rat. J Agric Food Chem 52(13):4338-4343. https:// doi.org/10.1021/jf0348323

69. Koistinen VM, Hanhineva K (2017) Microbial and endogenous metabolic conversions of rye phytochemicals. Mol Nutr Food Res. https://doi.org/10.1002/mnfr.201600627

70. Rondini L, Peyrat-Maillard MN, Marsset-Baglieri A, Berset C (2002) Sulfated ferulic acid is the main in vivo metabolite found after short-term ingestion of free ferulic acid in rats. J Agric Food Chem 50(10):3037-3041

71. Gonthier MP, Donovan JL, Texier O, Felgines C, Remesy C, Scalbert A (2003) Metabolism of dietary procyanidins in rats. Free Radic Biol Med 35(8):837-844. https://doi.org/10.1016/ s0891-5849(03)00394-0

72. Jakoby WB, Ziegler DM (1990) The enzymes of detoxication. J Biol Chem 265(34):20715-20718

73. Meyer UA, Zanger UM (1997) Molecular mechanisms of genetic polymorphisms of drug metabolism. Annu Rev Pharmacol Toxicol 37:269-296. https://doi.org/10.1146/annur ev.pharmtox.37.1.269

74. Meyer UA (1996) Overview of enzymes of drug metabolism. J Pharmacokinet Biopharm 24(5):449-459
75. Braune A, Bunzel M, Yonekura R, Blaut M (2009) Conversion of dehydrodiferulic acids by human intestinal microbiota. $\mathrm{J}$ Agric Food Chem 57(8):3356-3362. https://doi.org/10.1021/ jf900159h

76. Gonthier MP, Remesy C, Scalbert A, Cheynier V, Souquet JM, Poutanen K, Aura AM (2006) Microbial metabolism of caffeic acid and its esters chlorogenic and caftaric acids by human faecal microbiota in vitro. Biomed Pharmacother 60(9):536-540. https ://doi.org/10.1016/j.biopha.2006.07.084

77. Koch J, Eisenreich W, Bacher A, Fuchs G (1993) Products of enzymatic reduction of benzoyl-CoA, a key reaction in anaerobic aromatic metabolism. Eur J Biochem 211(3):649-661

78. Harwood CS, Burchhardt G, Herrmann H, Fuchs G (1998) Anaerobic metabolism of aromatic compounds via the benzoylCoA pathway. FEMS Microbiol Rev 22(5):439-458. https://doi. org/10.1016/S0168-6445(98)00026-6

79. Gao J, Ellis LB, Wackett LP (2010) The University of Minnesota biocatalysis/biodegradation database: improving public access. Nucleic Acids Res 38(Database issue):D488-D491. https://doi. org/10.1093/nar/gkp771

80. Vetrani C, Rivellese AA, Annuzzi G, Adiels M, Borén J, Mattila I, Orešič M, Aura AM (2016) Metabolic transformations of dietary polyphenols: comparison between in vitro colonic and hepatic models and in vivo urinary metabolites. J Nutr Biochem 33:111-118. https://doi.org/10.1016/j.jnutbio.2016.03.007

81. Bach Knudsen KE, Serena A, Bjørnbak Kjær AK, Tetens I, Heinonen SM, Nurmi T, Adlercreutz H (2003) Rye bread in the diet of pigs enhances the formation of enterolactone and increases its levels in plasma, urine and feces. J Nutr 133(5):1368-1375

82. Roberts MS, Magnusson BM, Burczynski FJ, Weiss M (2002) Enterohepatic circulation: physiological, pharmacokinetic and clinical implications. Clin Pharmacokinet 41(10):751-790. https ://doi.org/10.2165/00003088-200241100-00005

83. Sawai Y, Kohsaka K, Nishiyama Y, Ando K (1987) Serum concentrations of rutoside metabolites after oral administration of a rutoside formulation to humans. Arzneimittelforschung 37(6):729-732

84. Rodriguez-Mateos A, Vauzour D, Krueger CG, Shanmuganayagam D, Reed J, Calani L, Mena P, Del Rio D, Crozier A (2014) Bioavailability, bioactivity and impact on health of dietary flavonoids and related compounds: an update. Arch Toxicol 88(10):1803-1853. https://doi.org/10.1007/s00204-014-1330-7

85. Vetrani C, Rivellese AA, Annuzzi G, Mattila I, Meudec E, Hyötyläinen T, Orešič M, Aura AM (2014) Phenolic metabolites as compliance biomarker for polyphenol intake in a randomized controlled human intervention. Food Res Int 63:233-238. https ://doi.org/10.1016/j.foodres.2014.01.018

86. Zanotti I, Dall'Asta M, Mena P, Mele L, Bruni R, Ray S, Del Rio D (2015) Atheroprotective effects of (poly)phenols: a focus on cell cholesterol metabolism. Food Funct 6(1):13-31. https://doi. org/10.1039/c4fo00670d

87. Bresciani L, Scazzina F, Leonardi R, Dall'Aglio E, Newell M, Dall'Asta M, Melegari C, Ray S, Brighenti F, Del Rio D (2016) Bioavailability and metabolism of phenolic compounds from wholegrain wheat and aleurone-rich wheat bread. Mol Nutr Food Res 60(11):2343-2354

88. Loader TB, Taylor CG, Zahradka P, Jones PJH (2017) Chlorogenic acid from coffee beans: evaluating the evidence for a blood pressure-regulating health claim. Nutr Rev 75(2):114-133. https ://doi.org/10.1093/nutrit/nuw057

89. Alam MA, Subhan N, Hossain H, Hossain M, Reza HM, Rahman MM, Ullah MO (2016) Hydroxycinnamic acid derivatives: a potential class of natural compounds for the management of lipid metabolism and obesity. Nutr Metab. https://doi.org/10.1186/ s12986-016-0080-3 
90. Santana-Gálvez J, Cisneros-Zevallos L, Jacobo-Velázquez DA (2017) Chlorogenic acid: recent advances on its dual role as a food additive and a nutraceutical against metabolic syndrome. Molecules. https://doi.org/10.3390/molecules22030358

91. Tajik N, Tajik M, Mack I, Enck P (2017) The potential effects of chlorogenic acid, the main phenolic components in coffee, on health: a comprehensive review of the literature. Eur J Nutr 56(7):2215-2244. https://doi.org/10.1007/s00394-017-1379-1

92. Upadhyay R, Mohan Rao LJ (2013) An outlook on chlorogenic acids-occurrence, chemistry, technology, and biological activities. Crit Rev Food Sci Nutr 53(9):968-984. https://doi. org/10.1080/10408398.2011.576319

93. Heitman E, Ingram DK (2017) Cognitive and neuroprotective effects of chlorogenic acid. Nutr Neurosci 20(1):32-39. https:// doi.org/10.1179/1476830514y.0000000146

94. Hoelzl C, Knasmuller S, Wagner KH, Elbling L, Huber W, Kager N, Ferk F, Ehrlich V, Nersesyan A, Neubauer O, Desmarchelier A, Marin-Kuan M, Delatour T, Verguet C, Bezencon C, Besson A, Grathwohl D, Simic T, Kundi M, Schilter B, Cavin C (2010) Instant coffee with high chlorogenic acid levels protects humans against oxidative damage of macromolecules. Mol Nutr Food Res 54(12):1722-1733. https://doi.org/10.1002/mnfr.201000048

95. Nabavi SF, Tejada S, Setzer WN, Gortzi O, Sureda A, Braidy N, Daglia M, Manayi A, Nabavi SM (2016) Chlorogenic acid and mental diseases: from chemistry to medicine. Curr Neuropharmacol. https://doi.org/10.2174/1570159x14666160325120625

96. Milenkovic D, Morand C, Cassidy A, Konic-Ristic A, TomásBarberán F, Ordovas JM, Kroon P, De Caterina R, RodriguezMateos A (2017) Interindividual Variability in biomarkers of cardiometabolic health after consumption of major plant-food bioactive compounds and the determinants involved. Adv Nutr Int Rev J 8(4):558-570. https://doi.org/10.3945/an.116.01362 3

97. Vinayagam R, Jayachandran M, Xu B (2016) Antidiabetic effects of simple phenolic acids: a comprehensive review. Phytother Res 30(2):184-199. https://doi.org/10.1002/ptr.5528

98. Meng S, Cao J, Feng Q, Peng J, Hu Y (2013) Roles of chlorogenic acid on regulating glucose and lipids metabolism: a review. Evid Based Complement Altern Med. https://doi. org $/ 10.1155 / 2013 / 801457$

99. Ounnas F, de Lorgeril M, Salen P, Laporte F, Calani L, Mena P, Brighenti F, Del Rio D, Demeilliers C (2017) Rye polyphenols and the metabolism of n-3 fatty acids in rats: a dose dependent fatty fish-like effect. Sci Rep 7:40162. https://doi.org/10.1038/ srep40162

100. Yamaguchi T, Chikama A, Mori K, Watanabe T, Shioya Y, Katsuragi Y, Tokimitsu I (2008) Hydroxyhydroquinone-free coffee: a double-blind, randomized controlled dose-response study of blood pressure. Nutr Metab Cardiovasc Dis 18(6):408-414. https ://doi.org/10.1016/j.numecd.2007.03.004

101. Mills CE, Flury A, Marmet C, Poquet L, Rimoldi SF, Sartori C, Rexhaj E, Brenner R, Allemann Y, Zimmermann D, Gibson GR, Mottram DS, Oruna-Concha M-J, Actis-Goretta L, Spencer JPE (2016) Mediation of coffee-induced improvements in human vascular function by chlorogenic acids and its metabolites: two randomized, controlled, crossover intervention trials. Clin Nutr. https://doi.org/10.1016/j.clnu.2016.11.013

102. Watanabe T, Arai Y, Mitsui Y, Kusaura T, Okawa W, Kajihara Y, Saito I (2006) The blood pressure-lowering effect and safety of chlorogenic acid from green coffee bean extract in essential hypertension. Clin Exp Hypertens 28(5):439-449. https://doi. org/10.1080/10641960600798655

103. Kozuma K, Tsuchiya S, Kohori J, Hase T, Tokimitsu I (2005) Antihypertensive effect of green coffee bean extract on mildly hypertensive subjects. Hypertens Res 28(9):711-718. https://doi. org/10.1291/hypres.28.711
104. Ochiai R, Chikama A, Kataoka K, Tokimitsu I, Maekawa Y, Ohishi M, Rakugi H, Mikami H (2009) Effects of hydroxyhydroquinone-reduced coffee on vasoreactivity and blood pressure. Hypertens Res 32(11):969-974. https://doi.org/10.1038/ hr.2009.132

105. Ward NC, Hodgson JM, Woodman RJ, Zimmermann D, Poquet L, Leveques A, Actis-Goretta L, Puddey IB, Croft KD (2016) Acute effects of chlorogenic acids on endothelial function and blood pressure in healthy men and women. Food Funct 7(5):2197-2203. https://doi.org/10.1039/c6fo00248j

106. Agudelo-Ochoa GM, Pulgarín-Zapata IC, Velásquez-Rodriguez CM, Duque-Ramírez M, Naranjo-Cano M, Quintero-Ortiz MM, Lara-Guzmán OJ, Muñoz-Durango K (2016) Coffee consumption increases the antioxidant capacity of plasma and has no effect on the lipid profile or vascular function in healthy adults in a randomized controlled trial. J Nutr. https://doi.org/10.3945/ jn.115.224774

107. Chikama A, Yamaguchi T, Ochiai R, Kataoka K, Tokimitsu I (2008) Effects of hydroxyhydroquinone-reduced coffee on blood pressure in high-normotensives and mild hypertensives. J Health Sci 54(2):162-173. https://doi.org/10.1248/jhs.54.162

108. Mubarak A, Bondonno CP, Liu AH, Considine MJ, Rich L, Mas E, Croft KD, Hodgson JM (2012) Acute effects of chlorogenic acid on nitric oxide status, endothelial function, and blood pressure in healthy volunteers: a randomized trial. J Agric Food Chem 60(36):9130-9136. https://doi.org/10.1021/jf303440j

109. Van Rymenant E, Van Camp J, Pauwels B, Boydens C, Vanden Daele L, Beerens K, Brouckaert P, Smagghe G, Kerimi A, Williamson G, Grootaert C, Van de Voorde J (2017) Ferulic acid4- $O$-sulfate rather than ferulic acid relaxes arteries and lowers blood pressure in mice. J Nutr Biochem 44:44-51. https://doi. org/10.1016/j.jnutbio.2017.02.018

110. Thom E (2007) The effect of chlorogenic acid enriched coffee on glucose absorption in healthy volunteers and its effect on body mass when used long-term in overweight and obese people. J Int Med Res 35(6):900-908. https://doi.org/10.1177/1473230007 03500620

111. Kotyczka C, Boettler U, Lang R, Stiebitz H, Bytof G, Lantz I, Hofmann T, Marko D, Somoza V (2011) Dark roast coffee is more effective than light roast coffee in reducing body weight, and in restoring red blood cell vitamin $\mathrm{E}$ and glutathione concentrations in healthy volunteers. Mol Nutr Food Res 55(10):15821586. https://doi.org/10.1002/mnfr.201100248

112. Soga S, Ota N, Shimotoyodome A (2013) Stimulation of postprandial fat utilization in healthy humans by daily consumption of chlorogenic acids. Biosci Biotechnol Biochem 77(8):16331636. https://doi.org/10.1271/bbb.130147

113. Lecoultre V, Carrel G, Egli L, Binnert C, Boss A, MacMillan EL, Kreis R, Boesch C, Darimont C, Tappy L (2014) Coffee consumption attenuates short-term fructose-induced liver insulin resistance in healthy men. Am J Clin Nutr 99(2):268-275

114. Annuzzi G, Bozzetto L, Costabile G, Giacco R, Mangione A, Anniballi G, Vitale M, Vetrani C, Cipriano P, Della Corte G, Pasanisi F, Riccardi G, Rivellese AA (2014) Diets naturally rich in polyphenols improve fasting and postprandial dyslipidemia and reduce oxidative stress: a randomized controlled trial. Am J Clin Nutr 99(3):463-471. https://doi.org/10.3945/ajcn.113.07344 5

115. Mena P, García-Aloy M, González-Sarrías A, Andrés-Lacueva C, Rodriguez-Mateos A, Gibney ER, Massaro M, Scoditti E, Combet E, Palma S, Dall'Asta M, Bresciani L, Urpi-Sarda M, Maksimova V, Morand C, Deligiannidou E, Chiavaroli L (2017) Inter-individual variability in response to the impact of hydroxycinnamic acids on cardiometabolic biomarkers: a systematic review and meta-analysis. http://www.crd.york.ac.uk/PROSP 
ERO/display_record.php?ID=CRD42016050790 (PROSPERO 2016 CRD42016050790)

116. Johnston KL, Clifford MN, Morgan LM (2003) Coffee acutely modifies gastrointestinal hormone secretion and glucose tolerance in humans: glycemic effects of chlorogenic acid and caffeine. Am J Clin Nutr 78(4):728-733

117. Van Dijk AE, Olthof MR, Meeuse JC, Seebus E, Heine RJ, Van Dam RM (2009) Acute effects of decaffeinated coffee and the major coffee components chlorogenic acid and trigonelline on glucose tolerance. Diabetes Care 32(6):1023-1025

118. Olthof MR, Van Dijk AE, Deacon CF, Heine RJ, Van Dam RM (2011) Acute effects of decaffeinated coffee and the major coffee components chlorogenic acid and trigonelline on incretin hormones. Nutr Metab 8:10. https://doi.org/10.1186/1743-7075-8-10

119. Soga S, Ota N, Shimotoyodome A (2017) Reduction in hydroxyhydroquinone from coffee increases postprandial fat utilization in healthy humans: a randomized double-blind, cross-over trial. Biosci Biotechnol Biochem 81(7):1433-1435. https://doi. org/10.1080/09168451.2017.1301802

120. Shivappa N, Prizment AE, Blair CK, Jacobs DR Jr, Steck SE, Hebert JR (2014) Dietary inflammatory index and risk of colorectal cancer in the Iowa Women's Health Study. Cancer Epidemiol Biomark Prev 23(11):2383-2392. https://doi. org/10.1158/1055-9965.epi-14-0537

121. Bakuradze T, Parra GAM, Riedel A, Somoza V, Lang R, Dieminger N, Hofmann T, Winkler S, Hassmann U, Marko D, Schipp D, Raedle J, Bytof G, Lantz I, Stiebitz H, Richling E (2014) Four-week coffee consumption affects energy intake, satiety regulation, body fat, and protects DNA integrity. Food Res Int 63:420-427. https://doi.org/10.1016/j.foodres.2014.05.032

122. Boettler U, Volz N, Pahlke G, Teller N, Kotyczka C, Somoza V, Stiebitz H, Bytof G, Lantz I, Lang R, Hofmann T, Marko D (2011) Coffees rich in chlorogenic acid or $N$-methylpyridinium induce chemopreventive phase II-enzymes via the Nrf2/ARE pathway in vitro and in vivo. Mol Nutr Food Res 55(5):798-802. https://doi.org/10.1002/mnfr.201100115

123. Cropley V, Croft R, Silber B, Neale C, Scholey A, Stough C, Schmitt J (2012) Does coffee enriched with chlorogenic acids improve mood and cognition after acute administration in healthy elderly? A pilot study. Psychopharmacology 219(3):737-749. https://doi.org/10.1007/s00213-011-2395-0

124. Camfield DA, Silber BY, Scholey AB, Nolidin K, Goh A, Stough C (2013) A randomised placebo-controlled trial to differentiate the acute cognitive and mood effects of chlorogenic acid from decaffeinated coffee. PLoS One 8(12):e82897

125. Rezazadeh K, Rezazadeh F, Ebrahimi-Mameghani M (2018) The effect of artichoke leaf extract supplementation on lipid and CETP response in metabolic syndrome with respect to Taq 1B CETP polymorphism: a randomized placebo-controlled clinical trial. Eur J Integr Med 17:112-118

126. Brown JE, Rice-Evans CA (1998) Luteolin-rich artichoke extract protects low density lipoprotein from oxidation in vitro. Free Radic Res 29(3):247-255

127. Gavrieli A, Fragopoulou E, Mantzoros CS, Yannakoulia M (2013) Gender and body mass index modify the effect of increasing amounts of caffeinated coffee on postprandial glucose and insulin concentrations; a randomized, controlled, clinical trial. Metabolism 62(8):1099-1106

128. Martínez-López S, Sarriá B, Mateos R, Bravo-Clemente L (2018) Moderate consumption of a soluble green/roasted coffee rich in caffeoylquinic acids reduces cardiovascular risk markers: results from a randomized, cross-over, controlled trial in healthy and hypercholesterolemic subjects. Eur J Nutr 58(2):865-878. https ://doi.org/10.1007/s00394-018-1726-x

129. Sarriá B, Martínez-López S, Sierra-Cinos JL, García-Diz L, Mateos R, Bravo-Clemente L (2018) Regularly consuming a green/roasted coffee blend reduces the risk of metabolic syndrome. Eur J Nutr 57(1):269-278

130. Stalmach A, Clifford MN, Williamson G, Crozier A (2011) Phytochemicals in coffee and the bioavailability of chlorogenic acids. In: Teas, cocoa and coffee: plant secondary metabolites and health. Wiley-Blackwell, pp 143-168

131. Ioakeimidis $\mathrm{N}$, Tzifos V, Vlachopoulos $\mathrm{C}$, Terentes-Printzios D, Georgakopoulos C, Tousoulis D (2018) Acute effect of coffee on aortic stiffness and wave reflections in healthy individuals: differential effect according to habitual consumption. Int J Food Sci Nutr 1-12

132. Jokura H, Watanabe I, Umeda M, Hase T, Shimotoyodome A (2015) Coffee polyphenol consumption improves postprandial hyperglycemia associated with impaired vascular endothelial function in healthy male adults. Nutr Res 35(10):873-881

133. Geng J, Nielsen J (2017) In silico analysis of human metabolism: reconstruction, contextualization and application of genomescale models. Curr Opin Syst Biol 2(Supplement C):29-38. https ://doi.org/10.1016/j.coisb.2017.01.001

134. Rosazza JP, Huang Z, Dostal L, Volm T, Rousseau B (1995) Review: biocatalytic transformations of ferulic acid: an abundant aromatic natural product. J Ind Microbiol 15(6):457-471

135. Moco S, Fo-PJ Martin, Rezzi S (2012) Metabolomics view on gut microbiome modulation by polyphenol-rich foods. J Proteome Res 11(10):4781-4790

136. Healy JB, Young LY, Reinhard M (1980) Methanogenic decomposition of ferulic acid, a model lignin derivative. Appl Environ Microbiol 39(2):436-444

137. Grbić-Galić D, Young LY (1985) Methane fermentation of ferulate and benzoate: anaerobic degradation pathways. Appl Environ Microbiol 50(2):292-297

138. Rothwell JA, Perez-Jimenez J, Neveu V, Medina-Remon A, M'Hiri N, Garcia-Lobato P, Manach C, Knox C, Eisner R, Wishart DS, Scalbert A (2013) Phenol-explorer 3.0: a major update of the phenol-explorer database to incorporate data on the effects of food processing on polyphenol content. Database (Oxford) 2013:bat070. https://doi.org/10.1093/database/bat070

139. Hadadi N, Hafner J, Shajkofci A, Zisaki A, Hatzimanikatis V (2016) ATLAS of biochemistry: a repository of all possible biochemical reactions for synthetic biology and metabolic engineering studies. ACS Synth Biol 5(10):1155-1166. https://doi. org/10.1021/acssynbio.6b00054 